\title{
Internal vein texture and vein evolution of the epithermal Shila-Paula district, southern Peru
}

\author{
Alain Chauvet ${ }^{1,6}$, Laurent Bailly ${ }^{2}$, Anne-Sylvie André ${ }^{3}$, Patrick Monié ${ }^{1}$, \\ Daniel Cassard ${ }^{2}$, Fernando Llosa Tajada ${ }^{4}$, Juan Rosas Vargas ${ }^{4}$ and Johann Tuduri ${ }^{5}$
}

(1) UMR 5573, ISTEEM, University of Montpellier II, cc. 60, F-34095 Montpellier Cedex 5, France

(2) REM, BRGM, BP 6009, F-45060 Orléans Cedex 2, France

(3) UMR 7566, G2R, University Henri Poincaré, BP 239, F-54506 Vandœuvre-lès-Nancy Cedex, France

(4) CEDIMIN S.A.C., Luis N. Saenz 447-449, Jesus Maria, Lima 21, Peru

(5) ISTO, CNRS-UMR 6113, University of Orléans, BP 6759, F-45067 Orléans Cedex 2, France

(6) Dynamique de la Lithosphère, CNRS-UMR 5573, University of Montpellier 2, cc 060, F34830 Montpellier Cedex 5, France

\section{Abstract}

The epithermal Shila-Paula $\mathrm{Au}-\mathrm{Ag}$ district is characterized by numerous veins hosted in Tertiary volcanic rocks of the Western Cordillera (southern Peru). Field studies of the ore bodies reveal a systematic association of a main E-W vein with secondary $\mathrm{N} 55-60^{\circ} \mathrm{W}$ veins - two directions that are also reflected by the orientation of fluid-inclusion planes in quartz crystals of the host rock. In areas where this pattern is not recognized, such as the Apacheta sector, vein emplacement seems to have been guided by regional $\mathrm{N} 40^{\circ} \mathrm{E}$ and $\mathrm{N} 40^{\circ} \mathrm{W}$ fractures. Two main vein-filling stages are identified. stage 1 is a quartz-adulariapyrite-galena-sphalerite-chalcopyrite-electrum-Mn silicate-carbonate assemblage that fills the main E-W veins. stage 2, which contains most of the precious-metal mineralization, is divided into pre-bonanza and bonanza substages. The pre-bonanza substage consists of a quartz-adularia-carbonate assemblage that is observed within the secondary $\mathrm{N} 45-60^{\circ} \mathrm{W}$ veins, in veinlets that cut the stage 1 assemblage, and in final open-space fillings. The two latter structures are finally filled by the bonanza substage characterized by a Fe-poor sphalerite-chalcopyrite-pyrite-galena-tennantite-tetrahedrite-polybasite-pearceite-electrum assemblage. The ore in the main veins is systematically brecciated, whereas the ore in the secondary veins and geodes is characteristic of open-space crystallization. Microthermometric measurements on sphalerite from both stages and on quartz and calcite from stage 2 indicate a salinity range of 0 to $15.5 \mathrm{wt} \% \mathrm{NaCl}$ equivalent and homogenization temperatures bracketed between 200 and $330^{\circ} \mathrm{C}$. Secondary $\mathrm{CO}_{2-}, \mathrm{N}_{2^{-}}$and $\mathrm{H}_{2} \mathrm{~S}$-bearing fluid inclusions are also identified. The age of vein emplacement, based on ${ }^{40} \mathrm{Ar} /{ }^{39} \mathrm{Ar}$ ages obtained on adularia of different veins, is estimated at around $11 \mathrm{Ma}$, with some overlap between adularia of stage 1 $(11.4 \pm 0.4 \mathrm{Ma})$ and of stage $2(10.8 \pm 0.3 \mathrm{Ma})$. A three-phase tectonic model has been constructed to explain the vein formation. Phase 1 corresponds to the assumed development of E-W sinistral shear zones and associated $\mathrm{N} 60^{\circ} \mathrm{W}$ cleavages under the effects of a NE-SW shortening direction that is recognized at Andean scale. These structures contain the stage 1 ore assemblage that was brecciated during ongoing deformation. Phase 2 is a reactivation of earlier structures under a NW-SE shortening direction that allowed the reopening of the preexisting schistosity and the formation of scarce $\mathrm{N} 50^{\circ} \mathrm{E}$-striking S2-cleavage planes filled by the stage 2 pre-bonanza minerals. Phase 3 coincides with the bonanza ore emplacement in 
the secondary $\mathrm{N} 45-60^{\circ} \mathrm{W}$ veins and also in open-space in the core of the main $\mathrm{E}-\mathrm{W}$ veins. Our combined tectonic, textural, mineralogical, fluid-inclusion, and geochronological study presents a complete model of vein formation in which the reactivation of previously formed tectonic structures plays a significant role in ore formation.

Keywords Vein system - Texture - Epithermal gold - Breccia - Structural control - Peru

\section{Introduction}

Epithermal deposits often occur in a convergent tectonic setting and associated with volcanism (e.g., White and Hedenquist 1995). They are shallow deposits (surface to 1-2 km depth) formed at low to moderate temperature, and are genetically linked to magmatic activity (Hedenquist and Lowenstern 1994). Commonly characterized by the presence of welldeveloped mineralized veins (especially in the case of low-sulfidation deposits, e.g., Heald et al. 1987; White and Hedenquist 1995), these systems provide favorable study sites for advancing our understanding of vein formation. Nevertheless, most studies devoted to this vein type have concentrated more directly on ore-forming factors such as: (1) the ore and alteration mineralogy, combined with chemical and textural aspects (e.g., Hayba et al. 1985; Petersen et al. 1990; Dong et al. 1995; White and Hedenquist 1995); (2) physico-chemical and isotopic characterization of the involved hydrothermal fluids (e.g., Bodnar et al. 1985; De Ronde and Blattner 1988; Moore et al. 1992; Matsuhisa and Aoki 1994; Hayashi et al. 2001); (3) the effects of boiling, mixing, and water/rock interaction on ore transport and deposition (e.g., Drummond and Ohmoto 1985; Reed and Spycher 1985; Cole and Drummond 1986); and (4) the lateral and vertical zoning of hydrothermal ore and gangue minerals (e.g., Cline et al. 1992; Plumlee 1994; Cooke and McPhail 2001; André-Mayer et al. 2002). Very few studies were focused on the geometric and textural aspects of mineralized epithermal veins in relation to the regional structural setting (e.g., Fletcher et al. 1989; Naito 1993; Horner and Enriquez 1999; Ponce and Glen 2002). Because low-sulfidation deposits occur mainly as veins and/or stockworks, one needs to understand the process of trap formation in which hydrothermal fluids have sufficient space to percolate. The role of preexisting tectonic structures as natural traps for hydrothermal fluids and ore deposition would, thus, seem to have been underestimated.

In this paper, we present a detailed structural and mineralogical analysis of the Shila-Paula vein system and give new insights into the analysis of internal vein filling to constrain the vein formation process. The tectonic framework that prevailed before or during vein formation was determined through field measurements and structural studies. Combined mineralogical, textural, microstructural, microthermometric, and geochronological data obtained on selected and oriented samples are used to propose a model of vein formation in which the respective roles of tectonism and fluid-assisted (hydraulic) fracturing (Gratier 1984) are discussed. Our concept is that former structures, reactivated and reopened in association with boiling processes, may play a significant role in vein filling and ore deposition. 


\section{The metallogenic provinces of southern Peru}

The Shila-Paula district is one of the many areas of low-sulfidation epithermal $\mathrm{Au}-\mathrm{Ag}$ deposits hosted by the Tertiary subaerial volcanic rocks of the Western Cordillera of southern Peru (Petersen 1965; Sillitoe 1976; Fig. 1). The huge volcanic units overlie deformed Mesozoic and Paleozoic strata (Newell 1949; Laubacher 1978; Klinck et al. 1986) and mark the establishment of a magmatic arc along the Western Cordillera during the Oligocene and through the Pliocene (Fletcher et al. 1989; Clark et al. 1990). Few volcanic groups are distinguished (Fig. 1). The oldest, the Tacaza Group, composed mainly of trachy-/basalticandesite and tuff, is interpreted as having been extruded across southeast-trending linear fractures and has been dated from Middle Oligocene ( $30 \mathrm{Ma}$ ) to Early Miocene (Fornari et al. 2002). The Tacaza Group is the best represented in the Shila-Paula district (Fig. 1). Depending on the area, it is overlain by Early to Middle Miocene ignimbrite (Palca Group), Middle Miocene andesitic to dacitic lava (Sillapaca Group) and Late Miocene to Pliocene ignimbrite and lava (Barroso Group).

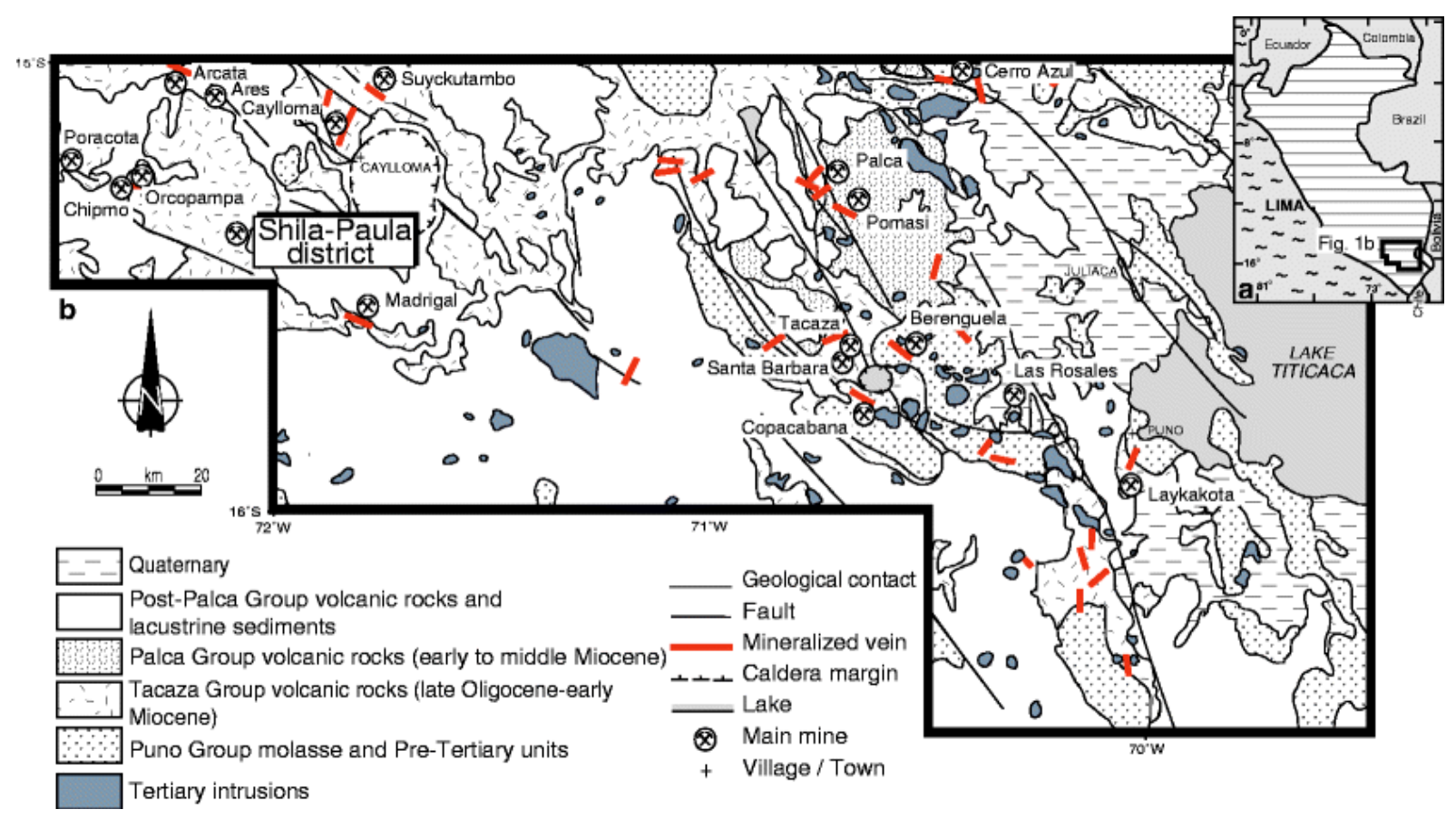

Fig. 1 Simplified geologic map of southern Peru showing the location of the main polymetallic deposits and the studied area (modified from Fletcher et al. 1989). Inset: location within Peru

A first inspection of the geological map of southern Peru shows two main structural trends that are expressed mainly by regional faults (Fig. 1). The first, striking $\mathrm{N} 50-60^{\circ} \mathrm{W}$, is better developed in the west and the second, close to $\mathrm{N} 30^{\circ} \mathrm{W}$, occurs mainly in the east. It should be noted that the major economic $\mathrm{Au}-\mathrm{Ag}$ ore deposits of the area are restricted to the western part dominated by $\mathrm{N} 60^{\circ} \mathrm{W}$ faults. The eastern domain essentially contains mineralization of low economic grade (Fig. 2 in Clark et al. 1990). 
The still active Orcopampa, Arcata, Shila-Paula, Ares, and Caylloma mines, as well as the Madrigal and Suyckutambo mines that ceased operating a few years ago, were already worked, mainly for gold and/or silver, at the time of the Incas, and continued operating through the period of the Spanish colonization to the present day. They belong generally to the low-sulfidation epithermal type (Candiotti et al. 1990; Petersen et al. 1990; Gibson et al. 1995; Jannas 1998), apart from the Suyckutambo mine and the recently discovered Chipmo and Poracota prospects (Orcopampa district), which are high-sulfidation type deposits (Ericksen and Cunningham 1993; Mayta 1999; Bradford 1999). The vein systems characterizing the mineralization were emplaced within the volcanic rocks of the Tacaza Group (Fletcher et al. 1989), some of them passing up into the overlying tuff of the Palca Group or down into the underlying Paleozoic and Mesozoic strata (Fletcher et al. 1989). All the deposits were recently included in a large-scale structural analysis that demonstrated a poor correlation between the mineralization and Tertiary intrusive bodies. A model promoting a deep origin for the fracture-channeled mineralizing fluids has been proposed and discussed (Fletcher et al. 1989).

\section{The Shila-Paula district}

Most of the exploited veins of the Shila-Paula district lie between 5,000 and more than $5,300 \mathrm{~m}$ above sea level (m.a.s.1.). Recent mining of the Shila veins started in 1989 by Cedimin S.A. and produced more than 400,000 tons of ore up to 1997, with approximately $10 \mathrm{~g} / \mathrm{t}$ of gold and approximately $260 \mathrm{~g} / \mathrm{t}$ of silver. Conversely, the Paula area is just entering into production and an active evaluation program is currently underway to estimate the reserves (Llosa Tejada et al. 2002). The Shila mine sensu stricto is composed of three distinct sectors, all characterized by numerous mineralized veins (Figs. 2 and 3a); two of these (Sando Alcalde and Pillune) lie at the western margin of the Shila pyroclastites, and the third one (Apacheta) is located within brecciated facies of the same unit. The mineralized veins of the Paula area are contained within dacite, andesite, and rhyodacite of the younger Fullchulna volcanic event (Fig. 2). Other small ore deposits, such as Los Desemparados, Ampato, Puncuhuayco, Ticlla, Colpa, and Tocracancha also occur in the district (Fig. 2), but their economic value has yet to be demonstrated 


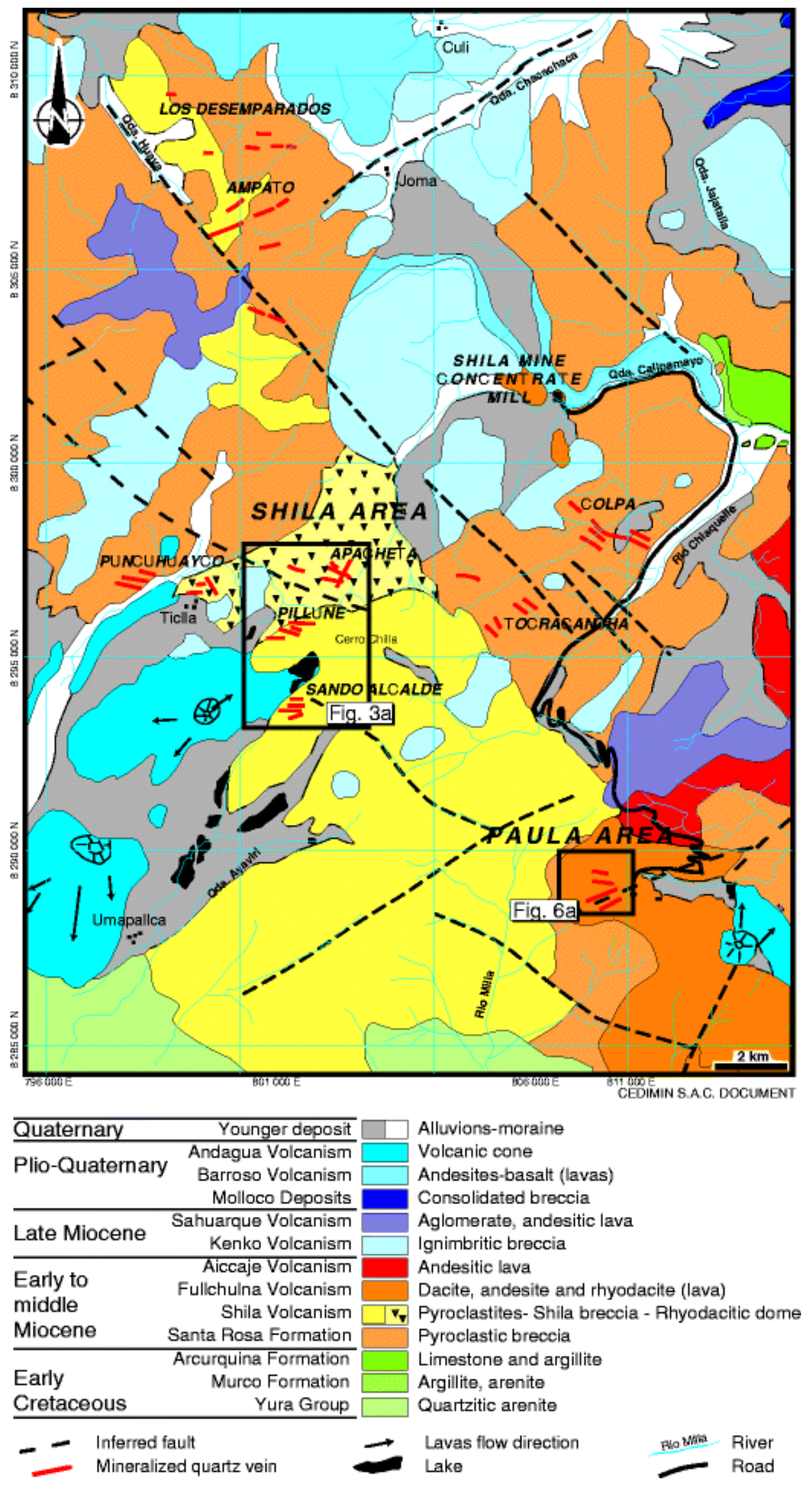

Fig. 2 Geologic map of the Shila-Paula district 

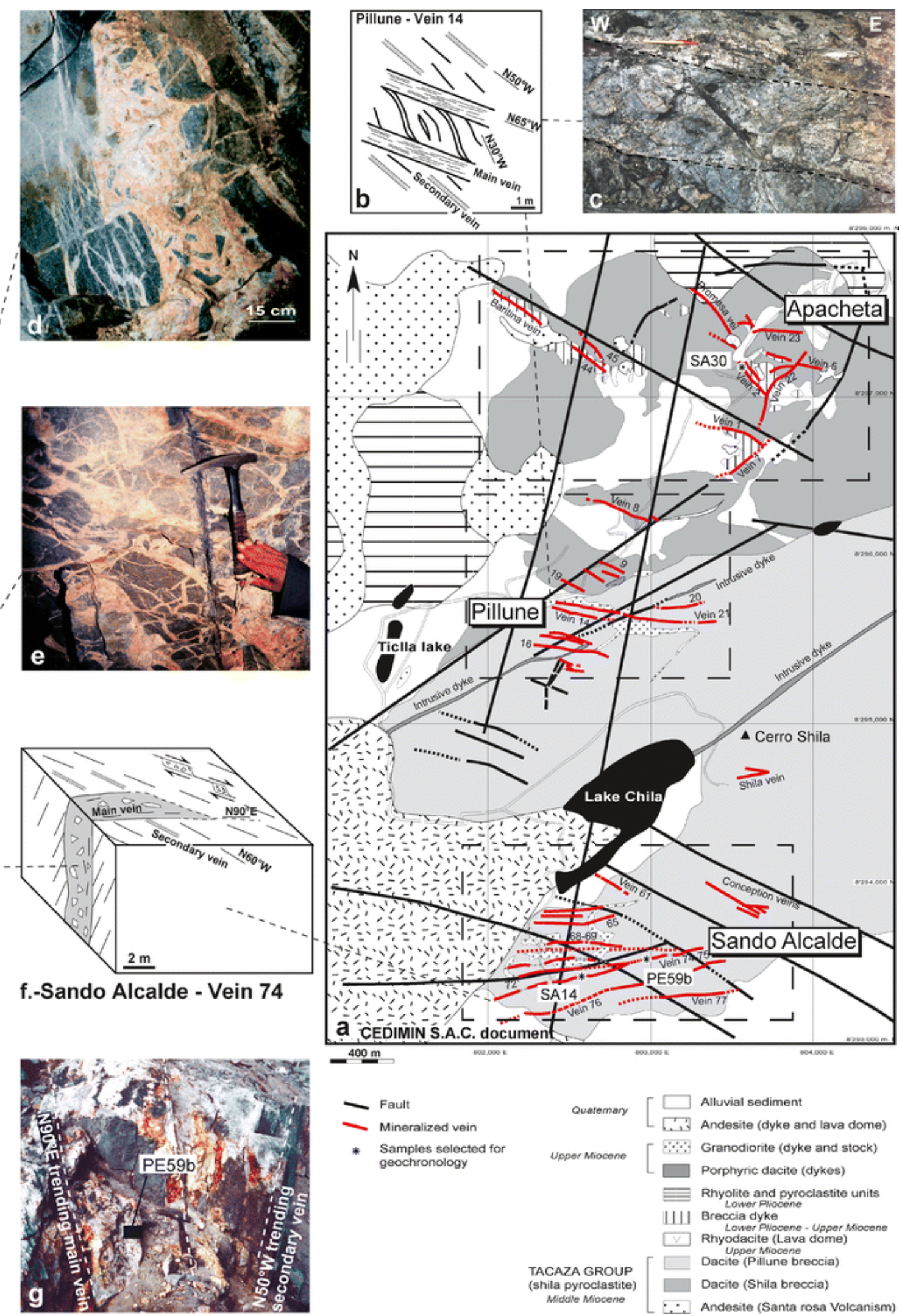

$-{ }^{400 \mathrm{~m}}$
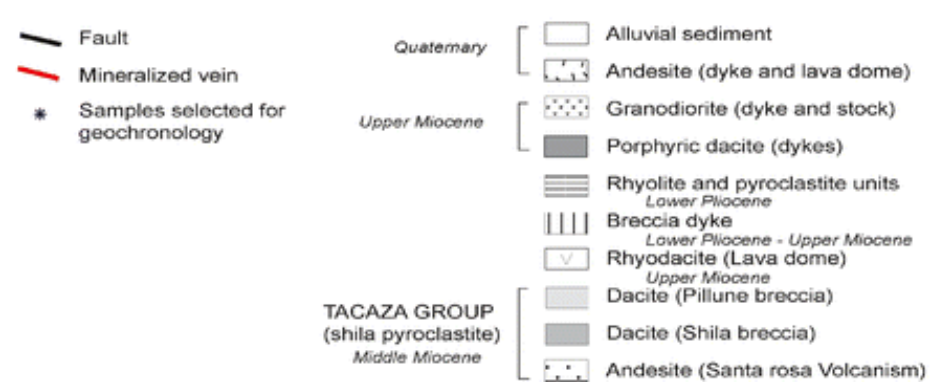

Fig. 3 Geometric and textural features of the Shila area. a Detailed geologic map of the Shila area showing, from north to south, the Apacheta, Pillune, and Sando Alcalde sectors. The locations of the three samples selected for ${ }^{40} \mathrm{Ar} /{ }^{39} \mathrm{Ar}$ dating is indicated. b and c Sketch (b) and corresponding photograph (c) of the Pillune sector (Vein 14). d-h. General aspects of Vein 74 showing the relationship between the main vein with an internal brecciated texture and the associated secondary open veins 


\section{Vein geometry}

At geological map scale, it appears that most of the mineralized veins of the Shila-Paula district display a fairly constant east-west strike (Fig. 3). Note that Bradford (1999) highlighted the role of E-W structures in Orcopampa, Chipmo, and Poracota. Plotting all the measurements made on the mineralized structures in a stereonet diagram (Fig. 4a) confirms the dominating E-W orientation. Nevertheless, it also appears that a set of data departs from this rule and that several mineralized veins have a $\mathrm{N} 60^{\circ} \mathrm{W}$ trend. Detailed examination of vein geometry in selected areas demonstrates that most of the mineralized structures consist of a single main vein segment associated with a few connected secondary veins. A systematic angular relationship exists between the two vein sets, with the secondary N45-60 $\mathrm{E}$ veins striking about $30^{\circ}$ clockwise from the main vein (Figs. 3b,f, and g, 5b, and 4b). The term 'secondary vein' is preferred in this paper to the term 'offshoot' defined by Stowell et al. (1999) because (a) the secondary veins do not originate from the main vein, and (b) we shall see later that the fillings of the two structures are neither coeval nor similar. The main veins can be as much as 1-2 m thick, whereas the secondary veins range from a few millimeters to, exceptionally, a few centimeters. This specific and systematic geometry could be considered as representative of most of the studied outcrops (Figs. 3 and 5). However, veins in the Apacheta sector do not show the same geometry as is well seen on the stereonet diagrams of Fig. 4c.
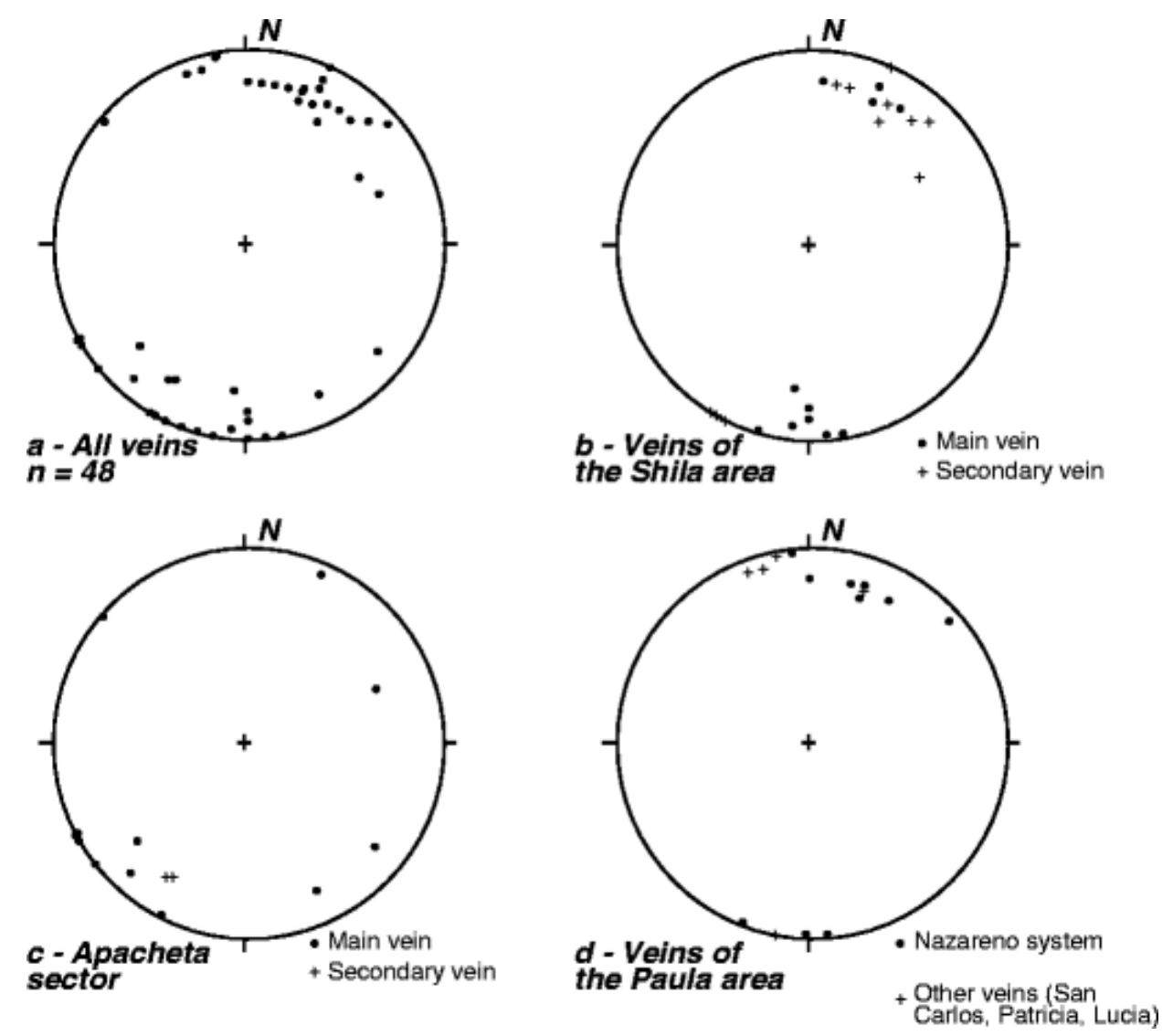

Fig. 4 a Stereonet diagram of all the mineralized veins and structures measured in the field. b Stereonet diagram showing the orientation of the main (dots) and secondary (crosses) veins within the Shila area. c Idem within the Apacheta sector. d Veins of the Paula area. Diagrams are Schmidt lower hemisphere projections 

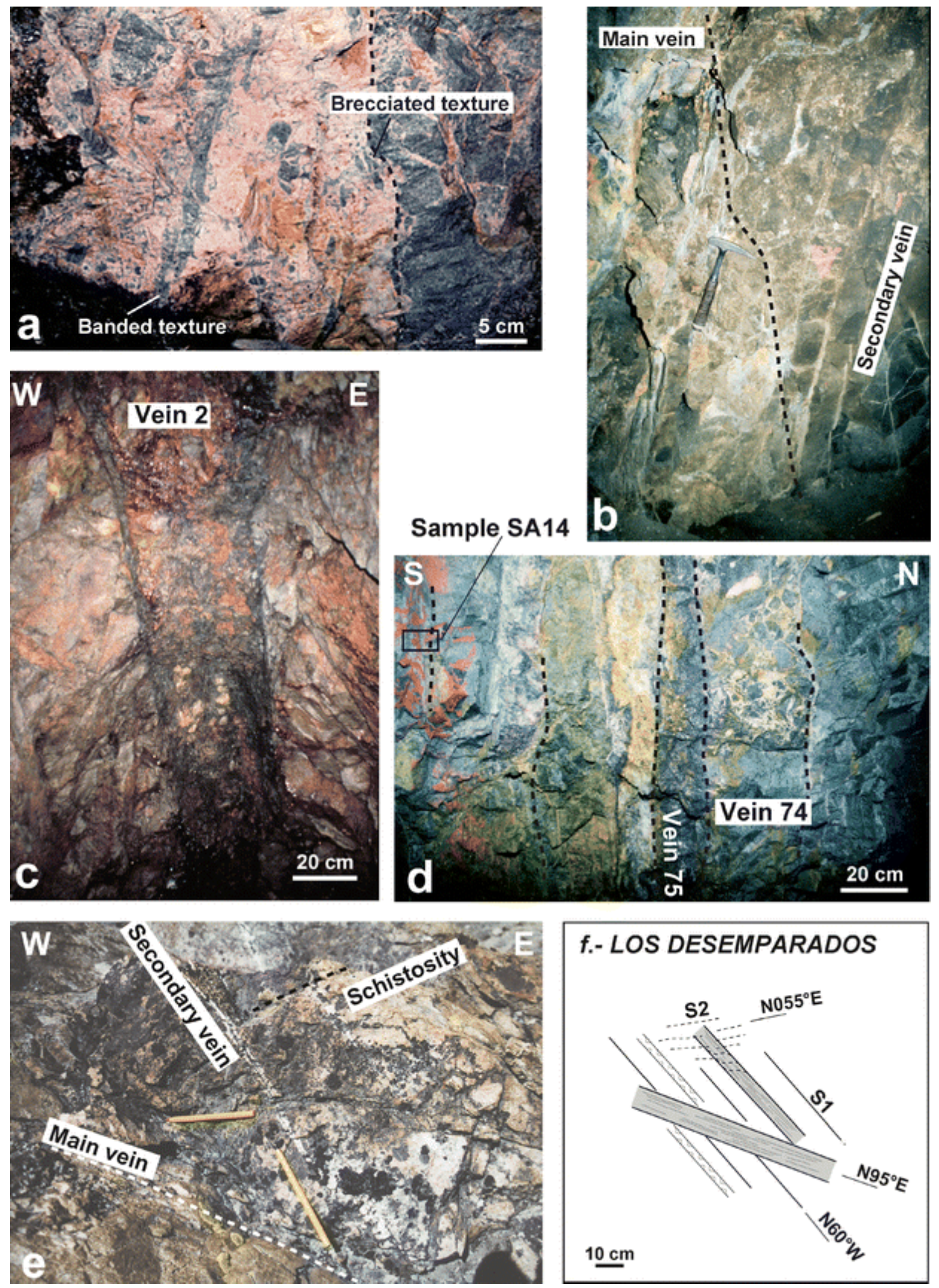

Fig. 5 a, b Common association between main and secondary veins at level 5,350 m (Sando Alcalde, Vein 74). c Brecciated aspect of Vein 2 of the Apacheta sector. d Underground mine view of Vein 75 crosscutting E-W trending mineralized veins. e and f Photograph (e) and corresponding sketch (f) of the Los Desemparados sector showing the presence of S2 cleavage affecting the main and secondary veins 


\section{Vein geometry in the Shila area}

In the Sando Alcalde sector, Vein 74 was analyzed in detail at different levels of the underground workings. The main vein is $1-2 \mathrm{~m}$ thick, strikes $\mathrm{N} 90^{\circ} \mathrm{E}$, dips $80^{\circ} \mathrm{N}$ and shows large breccia structures in its core (Figs. 3d,e, and 5a). Secondary fractures striking N70$70^{\circ} \mathrm{W}$ and dipping $90^{\circ}$ are recognized within the immediate host rocks on both sides of the main vein (Figs. $3 \mathrm{~g}$ and $5 \mathrm{~b}$ ). These secondary fractures are either incompletely filled by euhedral quartz grains perpendicular to the vein walls or completely healed. Small-scale pullapart structures are observed (Fig. $3 \mathrm{f}$ ). The structure is controlled by $\mathrm{N} 60^{\circ} \mathrm{W} / 90^{\circ}$ strike-slip faults that, according to the kinematics given by releasing overstep geometry, are dextral. The characteristic association between the $\mathrm{N} 80-90^{\circ} \mathrm{E}$ main vein and the $\mathrm{N} 50-70^{\circ} \mathrm{W}$ secondary fractures has also been observed in front of the level 5,350-m gallery (Fig. 3g). Vein 75 was recently discovered by mining geologists as a very rich vein that follows and locally overprints Vein 74 (Fig. 5d); striking $\mathrm{N} 90^{\circ} \mathrm{E}$ and about $10 \mathrm{~cm}$ thick, it is called 'bonanza' oreshoot containing the highest $\mathrm{Au}$ and Ag grades.

In the Pillune sector, Vein 14 (Fig. 3a) consists of two parallel $\mathrm{N} 65^{\circ} \mathrm{W}$ mineralized main veins with associated $\mathrm{N} 30^{\circ} \mathrm{W}$ sigmoid secondary veins between them (Fig. 3b,c). A network of thin secondary fractures with an average orientation close to $\mathrm{N} 50^{\circ} \mathrm{W} / 75^{\circ} \mathrm{SW}$ is seen around these veins. Kinematic observations along the veins located between the two branches demonstrate that the structure underwent a sinistral motion (Fig. 3c,d) followed by a dextral motion (Fig. 11c). Conversely, a neighboring $\mathrm{N} 65^{\circ} \mathrm{W}$ vein yields no sense of shearing - the significance of this observation is discussed later.

In the Apacheta sector, the vein system shows a drastically different pattern to that of the two previous sectors (Figs. 3a and 4c). Two main perpendicular vein directions are observed: $\mathrm{N} 40^{\circ} \mathrm{E}$ (e.g., Vein 22) and $\mathrm{N} 40^{\circ} \mathrm{W}$ (e.g., Veins 2 and 3; Fig. 5c). The sector is also characterized by numerous regional-scale $\mathrm{N} 40^{\circ} \mathrm{E}$ and $\mathrm{N} 40^{\circ} \mathrm{W}$ faults (Fig. 3a). Two other features also distinguish the Apacheta sector from the Sando Alcalde and Pillune sectors. First, the surrounding rocks essentially comprise volcanic dacitic breccia (the Shila volcanism breccia, Fig. 2), as is particularly well seen in the underground workings. Second, there is a complete absence of the secondary vein type.

\section{Vein geometry within the Paula area}

Veins of the Paula area strike mainly $\mathrm{N} 70^{\circ} \mathrm{E}$ to $\mathrm{N} 60^{\circ} \mathrm{W}$ (Figs. $4 \mathrm{~d}$ and $6 \mathrm{a}$ ). The $\mathrm{N} 75^{\circ} \mathrm{W}$ veins here do not appear as secondary veins of the main $\mathrm{E}-\mathrm{W}$ vein, but represent the richer ore bodies (e.g., the Nazareño system; Fig. 6a,b). The other vein trends are not economically significant (e.g., the $\mathrm{N} 70^{\circ} \mathrm{E}$ Patricia or San Carlos veins, and the $\mathrm{N} 90^{\circ} \mathrm{E}$ Lucia or Sofia veins; Fig. 6a). 


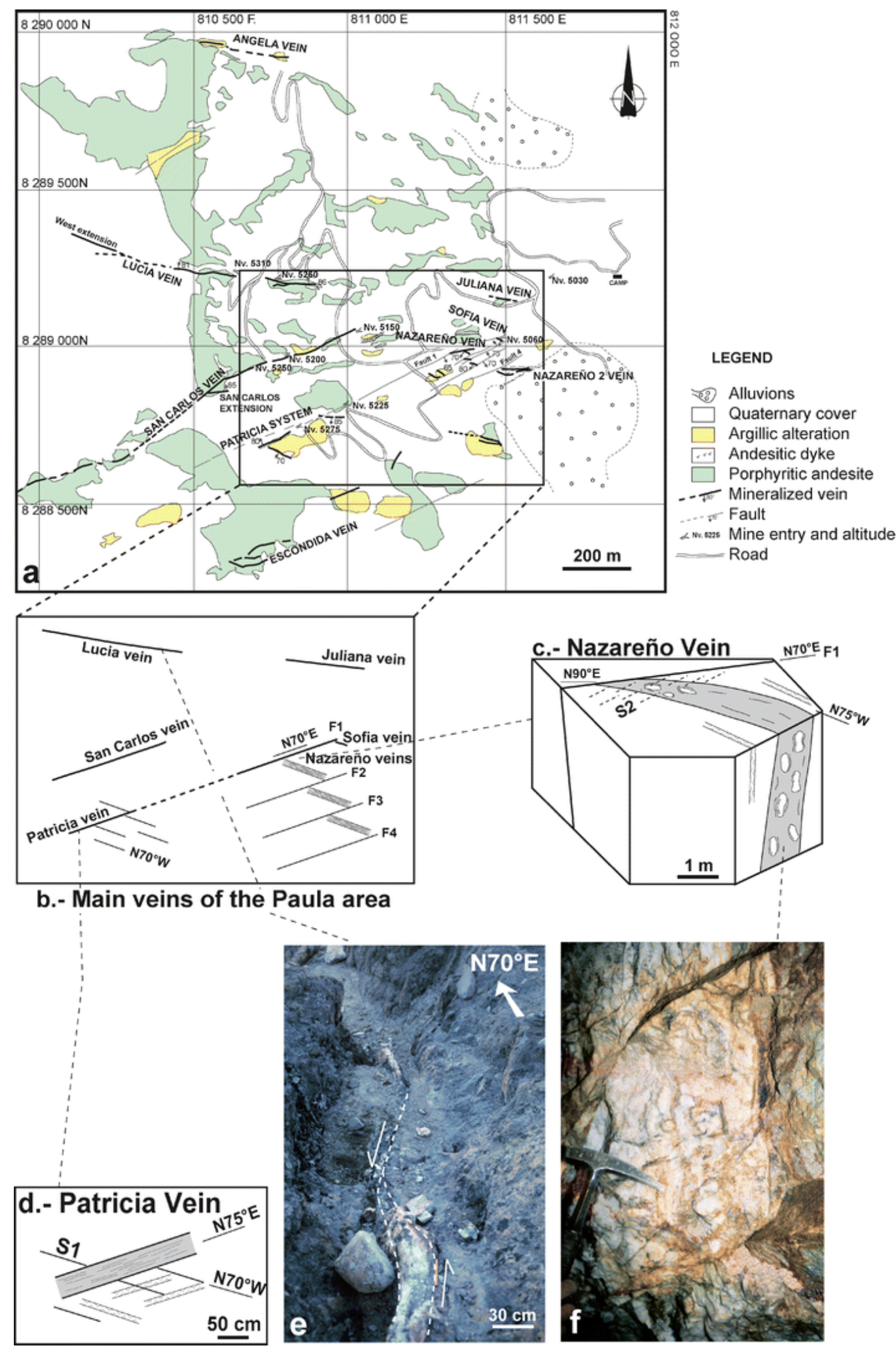

Fig. 6 Outcrops and map of the Paula area. a General map showing the arrangement of the different veins that make up the Paula district. b Simplified map of the Paula area showing relationships between the main mineralized veins (Nazareño system) and $\mathrm{N} 70^{\circ} \mathrm{E}$ faults. c Block diagram illustrating the general aspect of a Nazareño branch. d Presence of main and secondary veins close to the Patricia vein. e Irregular shape of the Lucia vein indicating sinistral motion coeval with quartz filling (see text for explanation). f Close-up of the Nazareño vein characterized by banded textures, geodes, and scarce cockades 
The Nazareño system is composed of three vein branches that define an 'en echelon' geometry due to be offset by a N70 ${ }^{\circ} \mathrm{E}$ fault swarm (F1 to F4, Fig. 6b). Vein thickness can be as much as 1 to $2 \mathrm{~m}$ (Fig. 6c,f). At this stage of the study, it is not clear whether or not these four faults could predate the mineralization. The fact that Faults 1 and 4 are mineralized along segments in contact with the Nazareño branches may indicate that they, at least, predate the mineralized event and that segments in contact with gold-bearing veins can be impregnated by mineralized fluids. This point underlines the potentially significant role of the two faults during vein formation. No secondary veins are observed, although a weak secondary $\mathrm{N} 50^{\circ} \mathrm{E}$ cleavage (S2) is observed in places (Fig. 6c). More recently, a continuation of the Nazareño system veins was discovered farther to the east (Nazareño 2).

The poorly economic Patricia and San Carlos veins are aligned along N70 E faults (Fig. 6b). The Patricia system exhibits a segment parallel to the Nazareño system, but without economic values. The E-W Lucia vein exhibits irregular segments, with the thinner segments striking $\mathrm{N} 90^{\circ} \mathrm{E}$ and the thicker ones striking $\mathrm{N} 70^{\circ} \mathrm{E}$ (Fig. 6e); such a geometry could be interpreted as left-lateral pull-apart occurring during vein formation.

\section{Other vein occurrences and appearance of a second schistosity}

Other variably mineralized quartz vein systems are widespread within the Shila-Paula district (e.g., Ampato, Los Desemparados, Puncuhuayco, Tocracancha, and Colpa; Fig. 2). Of note in these areas, apart from Los Desemparados and Ampato that strike E-W and NE-SW, respectively, is that when the veins lie close to regional faults they more or less parallel the faults (Fig. 2). None of the deposits show significant economic potential, but a few of them have a secondary schistosity that comprises an additional tectonic feature with respect to the 'main and secondary vein' system defined above. This is best expressed in the Los Desemparados prospects (Fig. 5e,f), where Vein 4 comprises a main $\mathrm{N} 85^{\circ} \mathrm{W}$ segment associated with secondary $\mathrm{N} 60^{\circ} \mathrm{W}$ veinlets. The system is, thus, consistent with the specific setting defined for the Sando Alcalde and Pillune sectors, but the presence of an additional NE-trending cleavage is observed (Fig. 5e,f). A similar cleavage with the same orientation has been reported in the Tocracancha and Ticlla outcrops (Fig. 3d,g in Cassard et al. 2000). The significance of this weakly developed and scarcely observed cleavage is discussed later.

\section{Mineralogy and texture}

A synthetic two-stage paragenetic succession that is valid at the regional scale has been reconstructed (Table 1). Because the two stages contain similar minerals throughout, their distinction is based on the presence or absence of specific phases, their chemical compositions, their textures, and their specific location within the main or secondary veins. Electron microprobe and SEM analyses completed the microscopic observations. Combined mineralogical and textural features are summarized in synoptic block diagrams for the Sando Alcalde and Nazareño veins, which are assumed to be representative of the Shila and Paula area vein systems, respectively (Fig. 7). 
Table 1 : Paragenetic succession of ore and gangue minerals, textural features, and texture distribution in the Shila-Paula gold-bearing veins

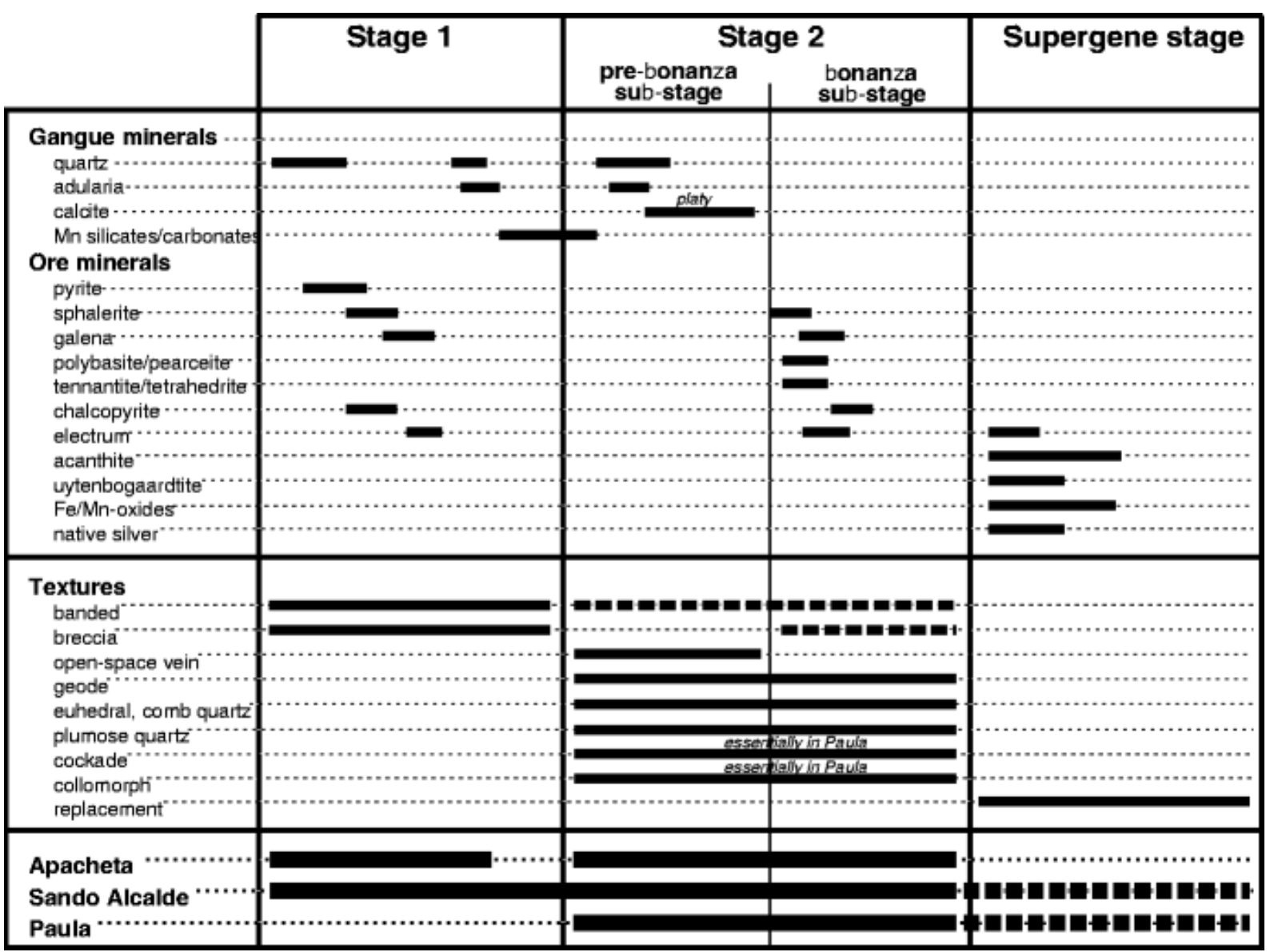



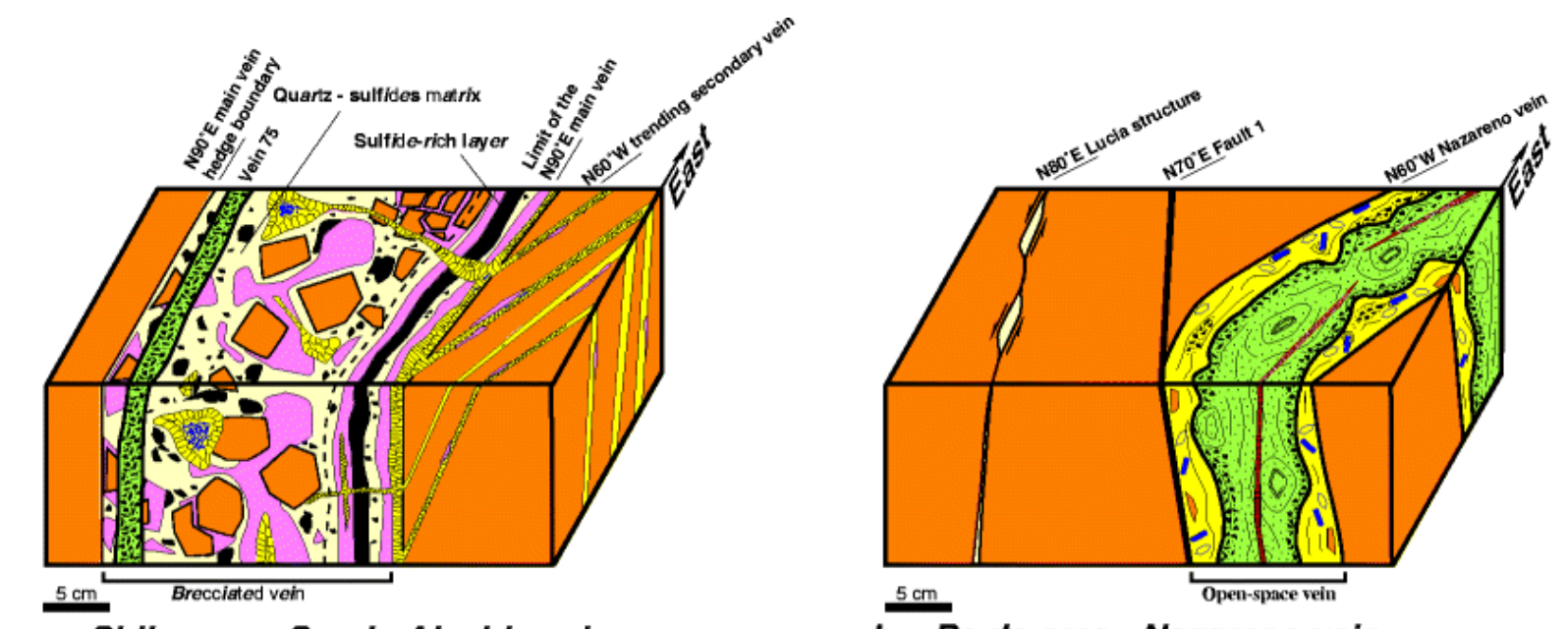

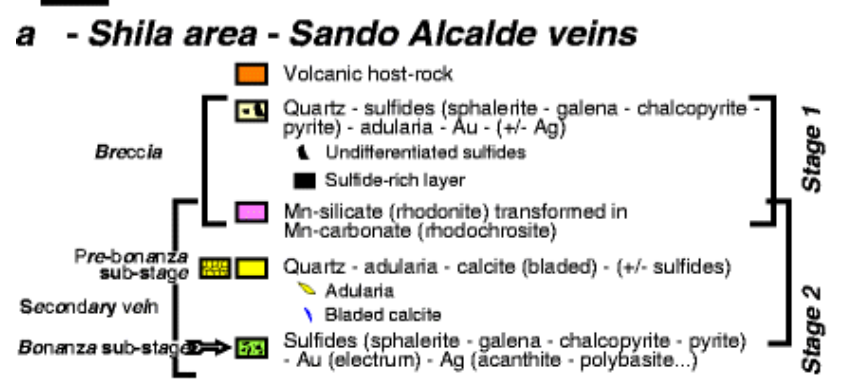
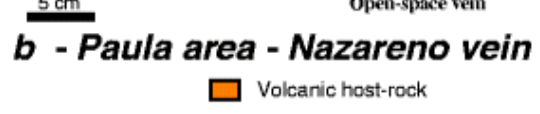

Barren stage $\square$ Quartz

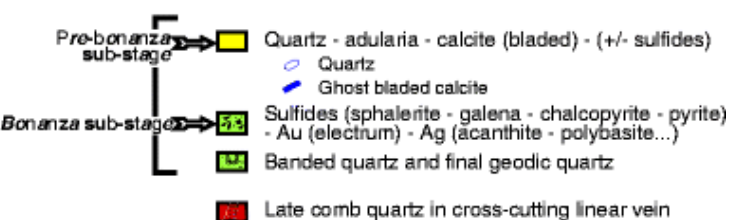

Fig. 7 Schematic and representative block diagrams summarizing the textural and mineralogical features of a the Sando Alcalde and $\mathbf{b}$ the Nazareño vein systems

\section{Mineralogy}

Hydrothermal alteration around the veins consists mainly of an intense host-rock sericitization that can extend up to $3 \mathrm{~m}$ from the vein wall. All the primary magmatic phases (feldspar, biotite, amphibole) are affected (Figs. 8a and 11e) and small pyrite crystals are scattered throughout the altered rock. Replacement of magmatic feldspar by adularia is commonly observed (Fig. 11e). 

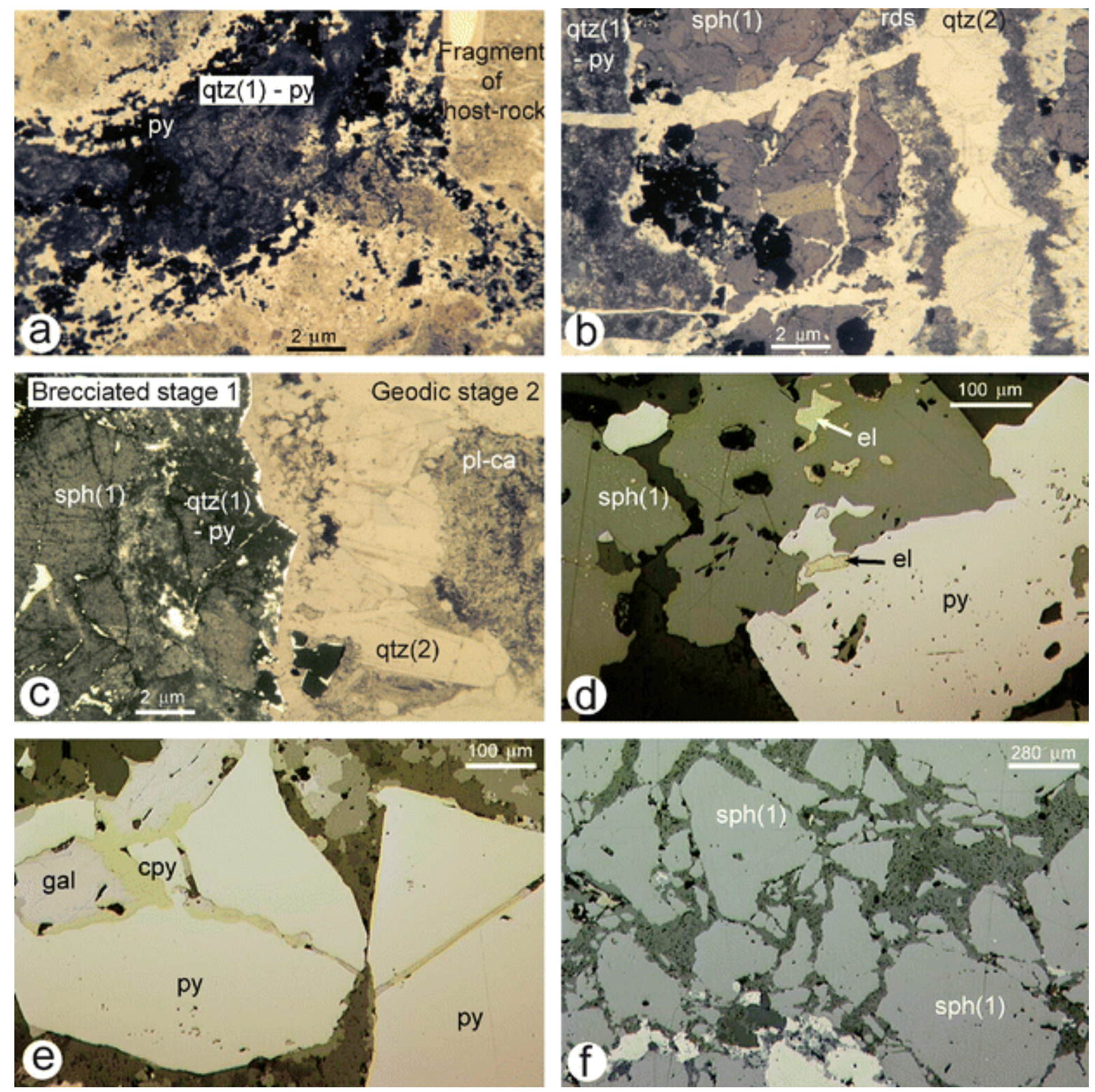

Fig. 8 Photographs of the textural and mineralogical features characteristic of stage 1 at Sando Alcalde (a, b, c, d) and Apacheta (e, f). a Breccia of volcanic host-rock elements cemented by stage 1-related quartz and pyrite. $\mathbf{b}$ Banded stage 1 paragenesis crosscut by stage 2-related quartz. c Transition from brecciated stage 1 toward stage 2 geodes filled by plumose-rich quartz and bladed calcite. d Distribution of electrum within stage 1-related sulfides. e Pyrite 1 fractured by stage 2 tetrahedrite/tennantite-galena and chalcopyrite. f Sphalerite 1 brecciated by stage 2-related quartz and calcite veinlets. cpy chalcopyrite, el electrum, gal galena, py pyrite, pl-ca platy calcite, $q t z$ quartz, $r d s$ rhodochrosite, $s p h$ sphalerite

Stage 1, which has been recognized in the Apacheta, Sando Alcalde, and Pillune sectors, consists of quartz, adularia, Mn-silicates/carbonates, and base-metal sulfides associated with small amounts of electrum (Figs. 7a, and $8 \mathrm{a}-\mathrm{c}$ ). The sequence began with the deposition of microcrystalline quartz and pyrite associated with scattered adularia; these minerals in places occur as the matrix of a breccia that affects the volcanic host rocks (Fig. 8a,c). The quartz grains are heterogeneous in size and show no preferential growth orientation. The sequence continued with the deposition of galena, centimeter-scale yellow-brown sphalerite and chalcopyrite (Fig. 8b,e). Electrum is locally abundant as inclusions $(10-30 \mu \mathrm{m})$ in pyrite, 
sphalerite, chalcopyrite, or galena (Fig. 8d). The sphalerite is characterized chemically by an Fe content ranging between 0.34 and $1.70 \mathrm{wt} \%$ and by significant amounts of $\mathrm{Mn}$ (up to $0.37 \mathrm{wt} \%)$ and $\mathrm{Cd}(0.50$ to $1.53 \mathrm{wt} \%)$ in the Apacheta sector (Fig. 9a). In the Sando Alcalde sector, the sphalerites are characterized by Fe contents of between 0.50 and $2.00 \mathrm{wt} \%$ and a relative constant $\mathrm{Mn}$ value close to $0.70 \mathrm{wt} \%$ (Fig. 9a). The electrum composition ranges between 62.9 and $74.0 \mathrm{wt} \% \mathrm{Au}$ in both sectors (Fig. 9b). The sequence then continued with rare quartz and abundant rhodonite $\left(\mathrm{MnSiO}_{3}\right)$ crystallization that was intensively replaced by rhodochrosite $\left(\mathrm{MnCO}_{3}\right)$ (Figs. 8b, 10). Mn-bearing phases are systematically present within the Sando Alcalde samples, but only weakly developed within the Apacheta ones.
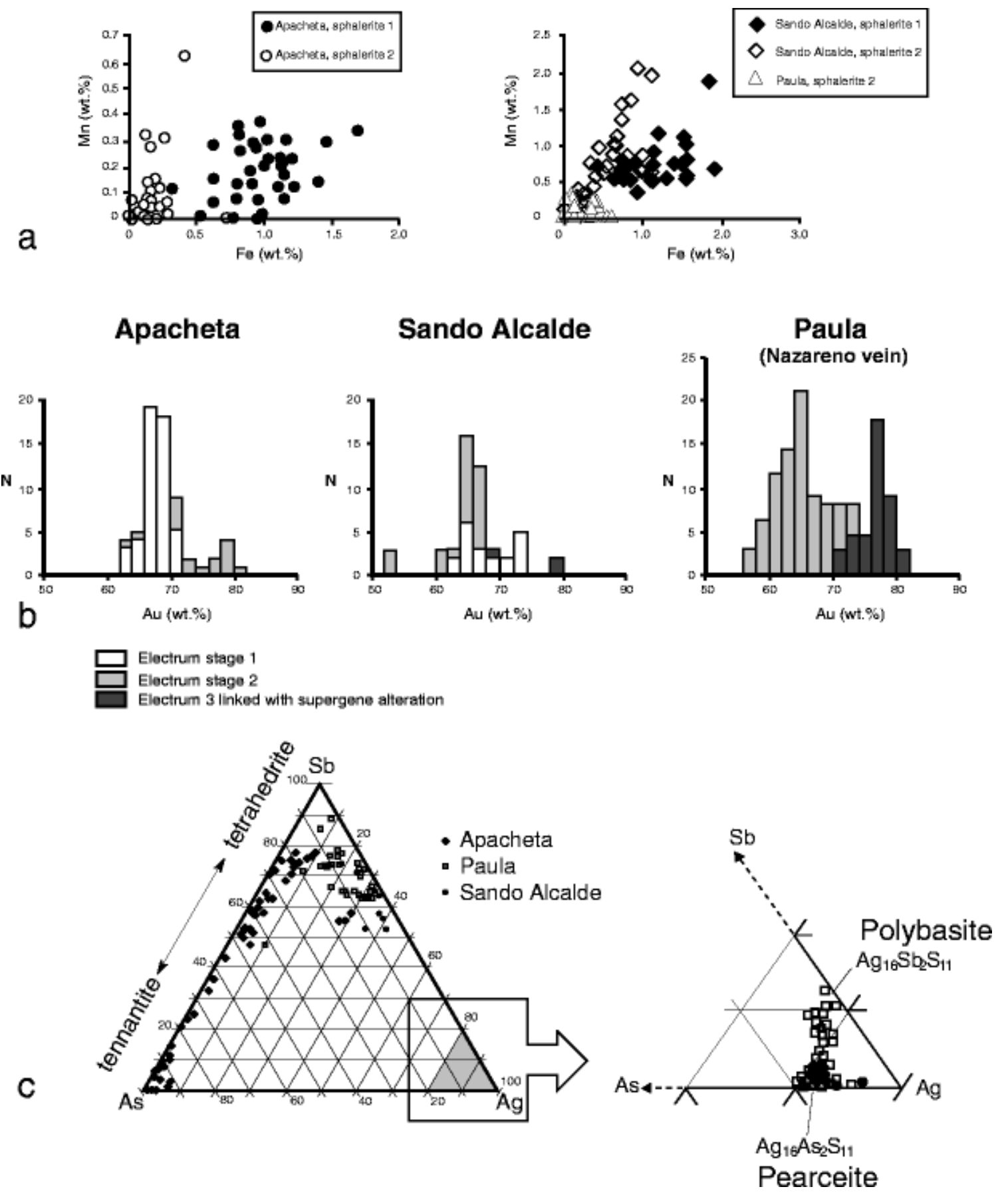

Fig. 9 Chemical characteristics of sphalerite (a), electrum (b), and silver-rich minerals (c) of the Shila-Paula mines 


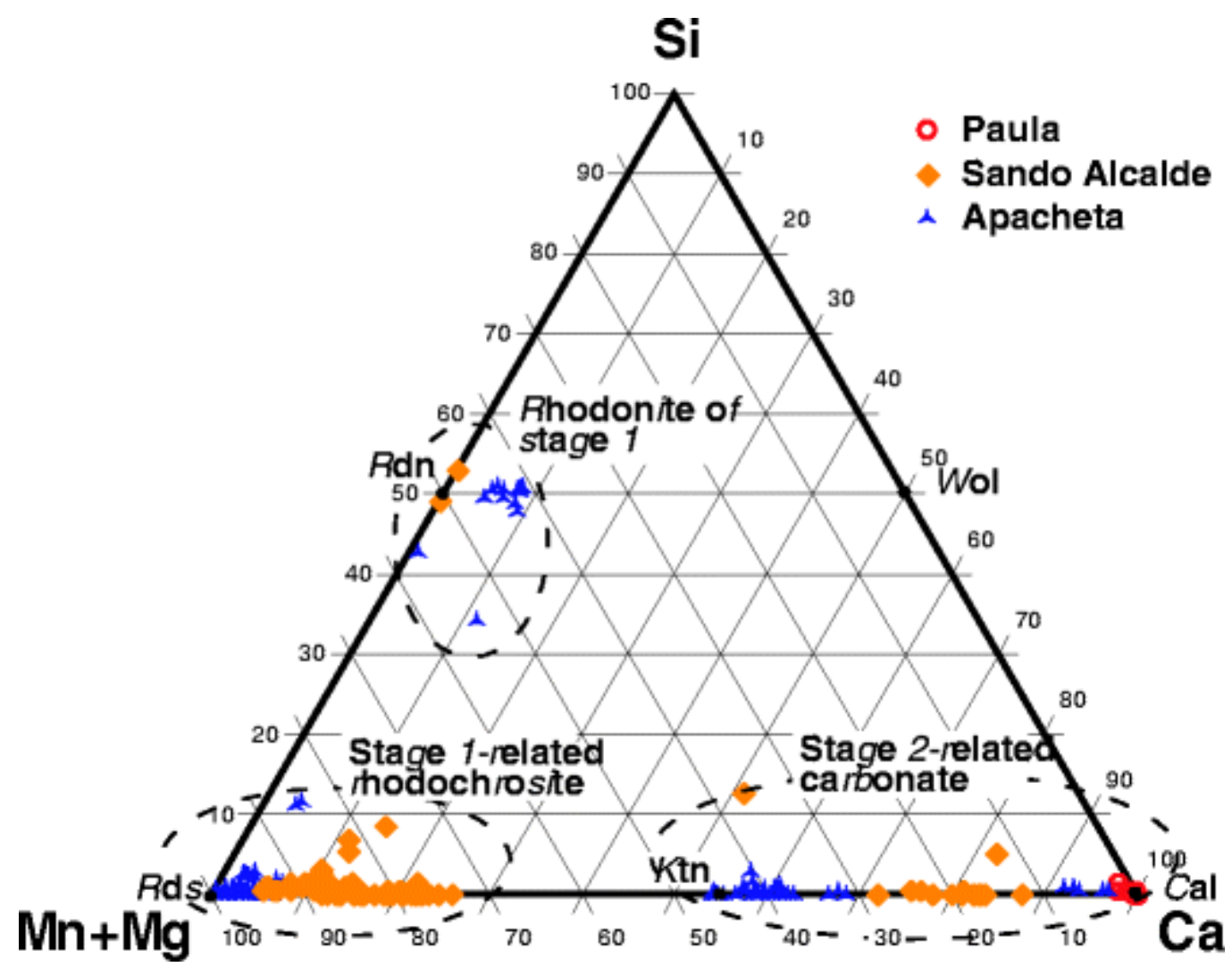

Fig. 10 Chemical composition of carbonates and Mn-rich silicates of the Shila-Paula mines in a $\mathrm{Si} v \mathrm{Mn}+\mathrm{Mg}$ vs $\mathrm{Ca}$ diagram. $R d n$ rhodonite $\left[\mathrm{Mn}\left(\mathrm{SiO}_{3}\right)\right]$, Wol wollastonite $\left(\mathrm{CaSiO}_{3}\right)$, Ktn kutnahorite $\left(\mathrm{CaMn}\left(\mathrm{CO}_{3}\right)_{2}\right), \mathrm{Cal}$ calcite $\left(\mathrm{CaCO}_{3}\right)$, Rds rhodochrosite $\left[\mathrm{Mn}\left(\mathrm{CO}_{3}\right)_{2}\right]$

Stage 2 is found mainly within the $\mathrm{N} 60^{\circ} \mathrm{W}$ secondary veins (Fig. 11a,c-e) and the geodic structures of the main veins (Figs. 7a and 8c). It began with the crystallization of euhedral quartz, carbonate (in places with bladed calcite) and adularia, followed by the formation of a complex base- and precious-metal paragenesis (Table 1). Carbonates of this second stage are discriminated from those of the first stage within a $\mathrm{Si}$ vs $\mathrm{Mn}+\mathrm{Mg}$ vs Ca diagram (Fig. 10). Only stage 2-related carbonates are found within the Paula samples. The later stage 2-baseand precious-metal assemblage is called the 'bonanza' stage by mining geologists because of its higher gold and silver values. In the present study, we have subdivided stage 2 into a Prebonanza substage and a Bonanza substage. The characteristics of the two stages within the Apacheta, Sando Alcalde, and Paula samples are given below. 

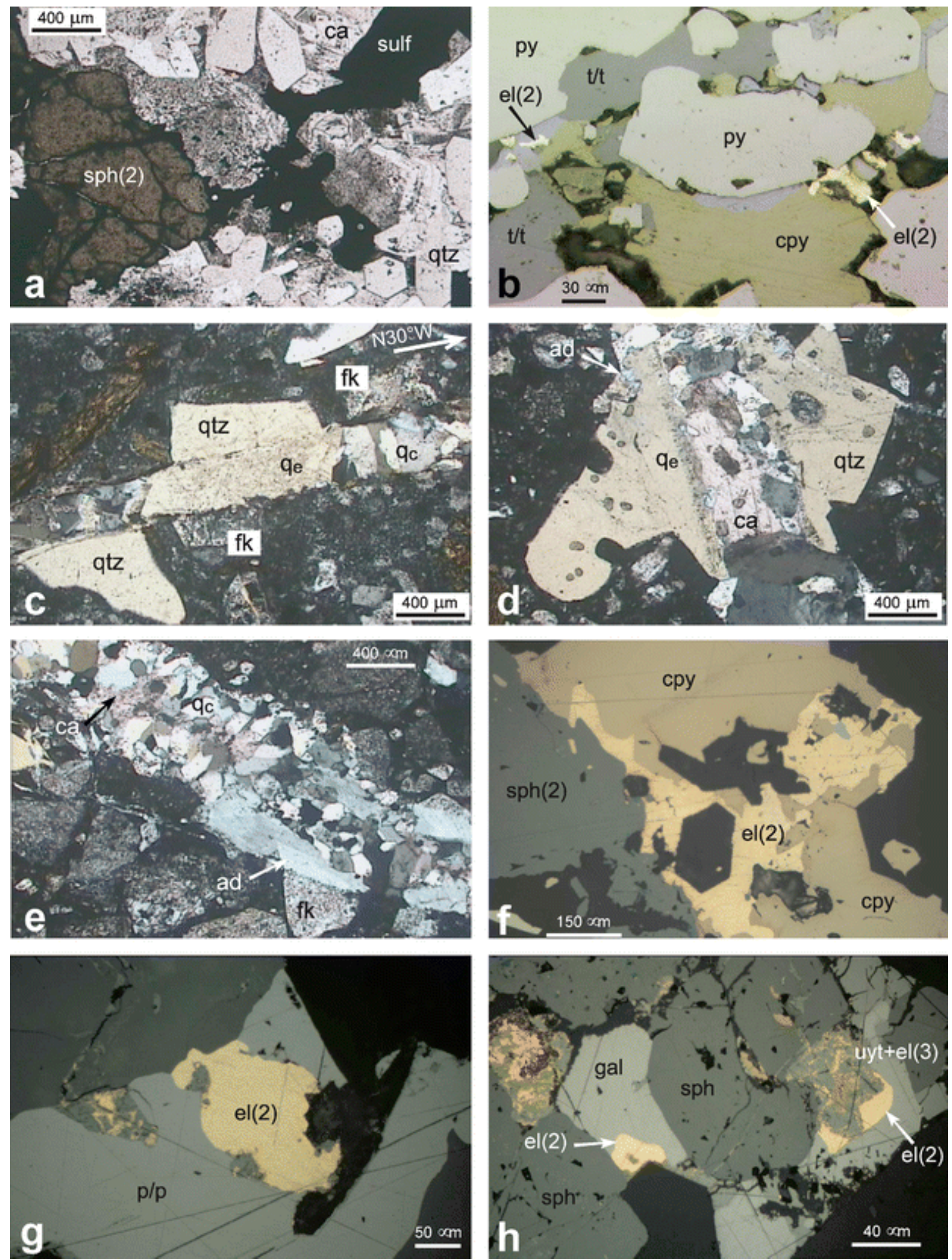

Fig. 11 Photographs of characteristic stage 2 textural and mineralogical features at Apacheta (a, b), Pillune (c), and Sando Alcalde $(\mathbf{d}-\mathbf{h})$. a Stage 2-related geodic filling with successive quartz, calcite, and sulfides in a sample from the Apacheta sector. b Representative stage 2 at Apacheta. c Secondary vein close to Vein 14 in the Pillune sector showing epitaxial quartz growth close to a large volcanic quartz and a small comb quartz in another part of the vein; note the dextral shearing of the earlier volcanic quartz. d Larger epitaxial growth of quartz achieved by calcite crystallization within a secondary vein of the Sando Alcalde sector-typical adularia 
crystals are associated with quartz overgrowth. e Comb quartz and epitaxial adularia within a secondary vein of the Sando Alcalde sector-note the intense sericitization of host-rock feldspars. $\mathbf{f}$ and g Typical stage 2 paragenesis in the Sando Alcalde sector-note the large size of electrum 2. h Stage 2 paragenesis with supergene effects developing electrum 3 and uytenbogaardtite. $a d$ adularia, $c a$ calcite, $c p y$ chalcopyrite, $e l$ electrum, $f k \mathrm{~K}-$ feldspar, gal galena, $p / p$ polybasite/pearceite, $p y$ pyrite, $q t z$ quartz, $q_{\text {e }}$ epitaxial quartz, $q_{\text {c }}$ comb quartz, $s p h$ sphalerite, sulf. sulfides, $t / t$ tennantite/tetrahedrite, uyt uytenbogaardtite

Apacheta sector Exceptionally in this sector, the Pre-bonanza substage (coarse comb quartz crystals and bladed calcite) occurs as a breccia matrix between stage 1 clasts (Fig. 8f). It was followed by the deposition of colorless sphalerite 2, with tennantite/tetrahedrite, electrum 2, galena, and chalcopyrite (Bonanza substage); the electrum appears as very fine grained inclusions in sulfide crystals (Fig. 11b). Sphalerite 2 shows a lower Fe content (up to $0.43 \mathrm{wt} \%$ ) with respect to the stage 1 sphalerite (Fig. 9a). Electrum 2 is enriched in $\mathrm{Au}$ (70 to $82 \mathrm{wt} \%$; Fig. 9b). Tetrahedrite, with an Ag content bracketed between 0 and $40 \mathrm{wt} \%$, is the main silver carrier up to level $5,150 \mathrm{~m}$ (Fig. 9c). A switch between the tennantite/tetrahedrite series minerals and the polybasite/pearceite minerals is observed at level $5,150 \mathrm{~m}$; the former are abundant below this level and the latter, with very scarce tennantite/tetrahedrite, occur above this level up to the surface.

Sando Alcalde sector The Bonanza substage consists of sphalerite, galena, chalcopyrite, polybasite/pearceite, acanthite, and electrum (Fig. 11f $-\mathrm{h}$ ). Compared with the Apacheta sector, tennantite/tetrahedrite occurrences are rare (Fig. 9c). Pseudomorphic replacement of polybasite/pearceite by acanthite is widespread. The Sando Alcalde sphalerite 2 exhibits an almost positive linear correlation between Fe and Mn (Fig. 9a), with chemical compositions evolving from low $\mathrm{Fe}$ and $\mathrm{Mn}$ (similar to sphalerite 2 from Apacheta) to higher Fe (up to $1.5 \mathrm{wt} \%$ ) and $\mathrm{Mn}$ (up to $2 \mathrm{wt} \%$ ). Replacement of electrum 2 grains by acanthiteuytenbogaardtite-Au-rich electrum 3 wires is commonly observed in the near-surface samples (Fig. 11h). This process has been ascribed to supergene alteration effects by Greffié et al. (2002). Electrum 2 shows a large compositional range (50 to $69 \mathrm{wt} \% \mathrm{Au}$ ), with $74 \%$ of the analyses falling in the 60-70 $\mathrm{wt} \% \mathrm{Au}$ range (Fig. 9b). Although there is no clear chemical difference between the stage 1 and stage 2 electrum, the electrum 3 wires resulting from the replacement of electrum 2 grains are systematically richer in $\mathrm{Au}(68.4$ to $79.5 \mathrm{wt} \% \mathrm{Au}$; Fig. 9b).

Paula area The only mineralization recognized within the Nazareño 1 and 2 veins at Paula is stage 2 (Fig. 7b). The depositional sequence began with the crystallization of large euhedral quartz, showing characteristic plumose textures, accompanied by bladed calcite (Pre-bonanza substage)(Fig. 12a,b). The silicification then continued as alternating bands of fine-grained and/or colloform quartz and millimeter-sized adularia (Fig. 12a,c). Relics of early quartz and calcite can be seen surrounded by this rhythmic quartz, and ghost-bladed textures are recognized in places (Fig. 12b). Very few Mn-rich minerals are present (Fig. 10). This, combined with the total absence of stage 1 minerals, is the main difference with the veins of the Shila area. The sequence continued with the Bonanza substage that here comprises quartz, sphalerite, galena, chalcopyrite, pyrite, polybasite/pearceite-tennantite/tetrahedrite, and electrum (Fig. 12d,e). At least two Bonanza substages are recognized, separated by quartz and adularia collomorph layers (Fig. 12c), and both polymetallic assemblages contain abundant electrum. Late barren comb-quartz veinlets, up to $3 \mathrm{~mm}$ thick and in places filled by late calcite, cut all the previously described assemblages (Fig. 12f). 

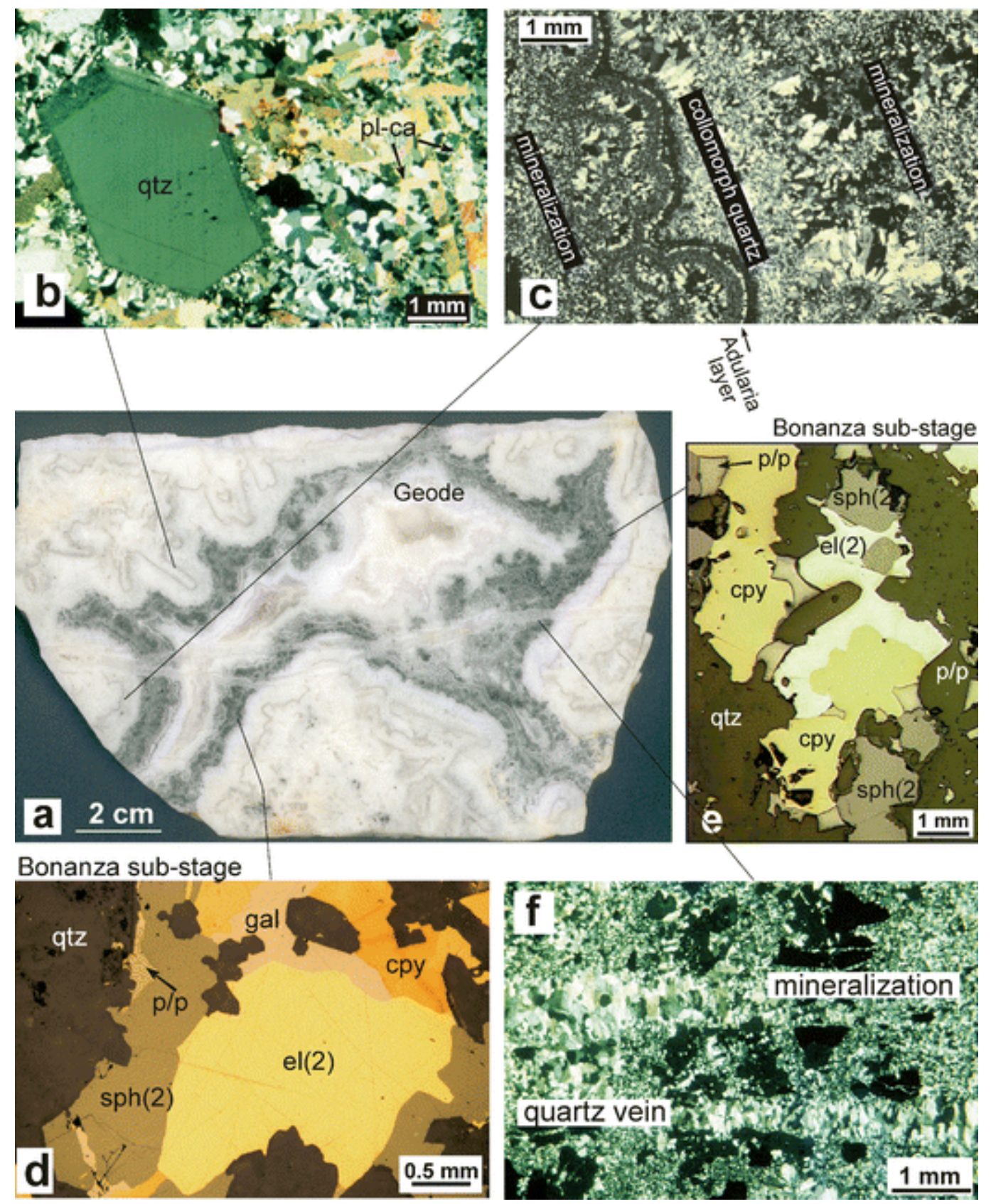

Fig. 12 Characteristic textures of the Nazareño vein samples a Photograph of a section representative of the Paula mineralization showing evolution from the first silicification stage toward the Bonanza sub-stage and late geodic filling. b Euhedral quartz $(q t z)$ and platy calcite $(p l-c a)$ marking the initiation of stage 2 and affected by the first silicification. c Collomorph quartz and adularia located between two distinct Bonanza sub-stages. d and e Bonanza substage represented by a large electrum 2 (el) associated with chalcopyrite (cpy), quartz (qtz), galena $(\mathrm{gal})$, polybasite/pearceite $(\mathrm{p} / \mathrm{p})$ and sphalerite $(\mathrm{sph})$. f Late quartz vein crosscutting all previous stages

The chemical composition of sphalerite in the Paula area is similar to that of the stage 2related sphalerite in the Apacheta sector. Sphalerite has less than $1.0 \mathrm{wt} \% \mathrm{Fe}$ with traces of Mn (around $0.2 \mathrm{wt} \%$ ) and Cd (up to $0.4 \mathrm{wt} \%$; Fig. 9a). Minerals of the polybasite/pearceite series and argentiferous tetrahedrite (up to $8 \mathrm{wt} \% \mathrm{Ag}$ ) are the principal Ag-carriers within the Paula samples (Fig. 9c). Acanthite and native silver remain subordinate. Electrum grains, abundant and up to $2 \mathrm{~mm}$ in diameter (Fig. 12d), are observed mainly as inclusions within polybasite/pearceite and chalcopyrite, although free grains do occur within quartz. Their 
compositions evolve from 56 to $74 \mathrm{wt} \% \mathrm{Au}$ (Fig. 9b). Destabilization features of the electrum grains, similar to those observed at Sando Alcalde, are well-developed within the Paula samples (Greffié et al. 2002). Secondary electrum wires (electrum 3), associated with acanthite-uytenbogaardtite and locally native silver, contains up to $82 \mathrm{wt} \% \mathrm{Au}$ (Fig. 9b).

\section{Texture}

The main veins and secondary veins have different internal textures (Table 1). Stage 1 is represented mainly within the main veins, whereas stage 2 fills the secondary veins and forms superposed phases within the main veins (Fig. 7).

Stage 1 occurs under the form of breccia and/or banded textures (Fig. 7a). Where the main veins have a banded texture, they show successive layers of quartz, sulfides, and rhodonite/rhodochrosite from the edge to the center, with maximum layer thickness being approximately $1 \mathrm{~cm}$ (Fig. 8b). The brecciated facies shows a different pattern with angular clasts of stage 1 quartz and sulfides occurring in a matrix of pink Mn-rich minerals (rhodonite/rhodochrosite; Fig. 8a,c). This demonstrates that the Mn-rich minerals were later in the stage 1 paragenesis. The exact nature of the breccia is difficult to determine. Tectonic processes cannot be excluded, as illustrated by the example in Fig. 3d, where rotated and displaced fragments are recognized. However, a fluid-assisted fracturing is also considered as locally probable, as illustrated by geometric puzzle figures (Fig. 3e, Gratier 1984; Jébrak 1997).

The stage 2-related minerals occur in structures that characterize the filling of open voids. This concerns the secondary veins and the geodes in the core of the main veins (Fig. 7a), which contain minerals unaffected by any kind of deformation (Figs. 8c and 11c-e). The initial filling in geodes is characterized by large euhedral, translucent comb and columnar quartz exhibiting plumose textures and growth bands (Fig. 8c); the plumose textures have been interpreted as evidence of polyphase crystallization (Dong et al. 1995). Comb quartz crystals are systematically oriented normal to the geode walls and design a concentric shape with a centripetal growth direction (Fig. 8c). The size of the quartz crystals appears to increase toward the vein center, where platy calcite can occur (Fig. 8c). The Bonanza stage, described above, would then have probably crystallized as a late filling (Fig. 11a).

Within the secondary veins, the common gangue minerals are quartz, adularia, and calcite (Fig. 11c-e). Small comb quartz crystals lie perpendicular to the vein walls (Fig. 11c,e) and calcite fills the vein centers (Fig. 11d). Adularia crystals along the vein borders show the typical diamond shape (Fig. 11d,e). Contrasting fillings and textures occur with respect to the nature of the immediate host rock. Where crossing the volcanic matrix, the veins are composed essentially of elongate quartz and triangular adularia, in places completed by a calcite filling (Fig. 11e, left part of the vein). Conversely, where the veins cross large volcanic quartz or feldspar grains, large quartz or adularia crystals, respectively, are found (Fig. 11ce). These overgrowths have similar optical characteristics to their host grains and in places occur as larger grains (Fig. 11d). This is a type of overgrowth that is poorly described in the literature, where it has been called 'oriented' or 'syntaxial' growth (Cox and Etheridge 1983). Because the term 'syntaxial' seems to be used in the sense of growth towards the vein center (Ramsay and Huber 1983), we prefer to use the term 'epitaxial' to characterize the controlled growth of a new grain with respect to a parent with the same optical characters. 
Samples from the Nazareño vein are characterized by the presence of banded textures, rare cockades, and geodes (Fig. 7b). These reflect successive crystallization in an environment apparently free from tectonic stress (Figs. 6f and 12a). The cockades are interpreted as reflecting the occurrence of hydraulic fracturing within open-space domains (Genna et al. 1996). A few samples show the succession of silica and polymetallic stages (Fig. 12c). The presence of collomorph quartz crystallization with alternating adularia-rich layers is common in epithermal environments (Dowling and Morrison 1989), and is an additional indication of stress-free crystallization (Fig. 12c).

\section{Fluid-inclusion constraints Geometry of the fluid inclusion planes}

The geometry of the fluid migration was studied for the Apacheta, Pillune, and Sando Alcalde sectors of the Shila area and for the small Los Desemparados occurrence. Identification of the fluid migration was made from an analysis of the Fluid Inclusion Planes (FIP), which are sealed microcracks (Fig. 13a) hosting fluid inclusions and, thus, indicators of the fluid percolation (Roedder 1984). They are considered as mode I cracks (Atkinson 1987) forming a network that is geometrically linked to the regional stress (e.g., Tuttle 1949; Lespinasse and Pêcher 1986). The orientation of the cracks is assumed to be parallel to the main compressive stress $\left(\sigma_{1}\right)$ and perpendicular to the extensional one $\left(\sigma_{3}\right)$ (Fig. 13b). Use of the FIP orientation in structural geology has been developed in different studies for establishing relationships between tectonic events and fluid percolation (e.g., Pêcher et al. 1985; Kowallis et al. 1987; Laubach 1989; Cathelineau et al. 1990; Lespinasse 1999; André et al. 2001). 
a
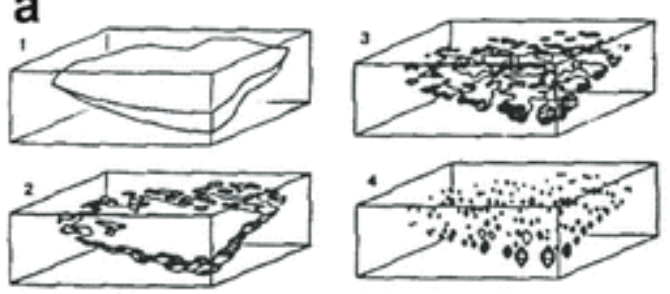

b

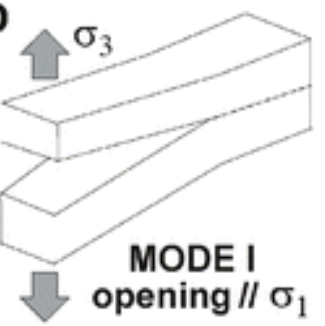

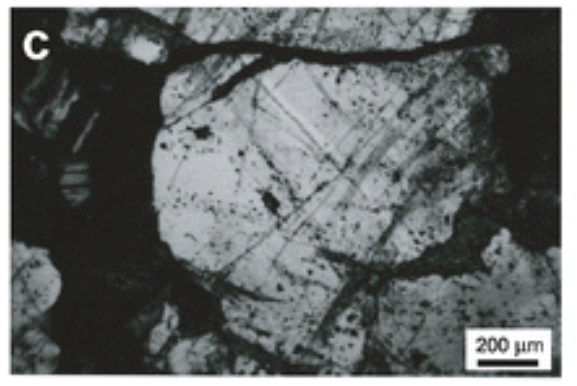
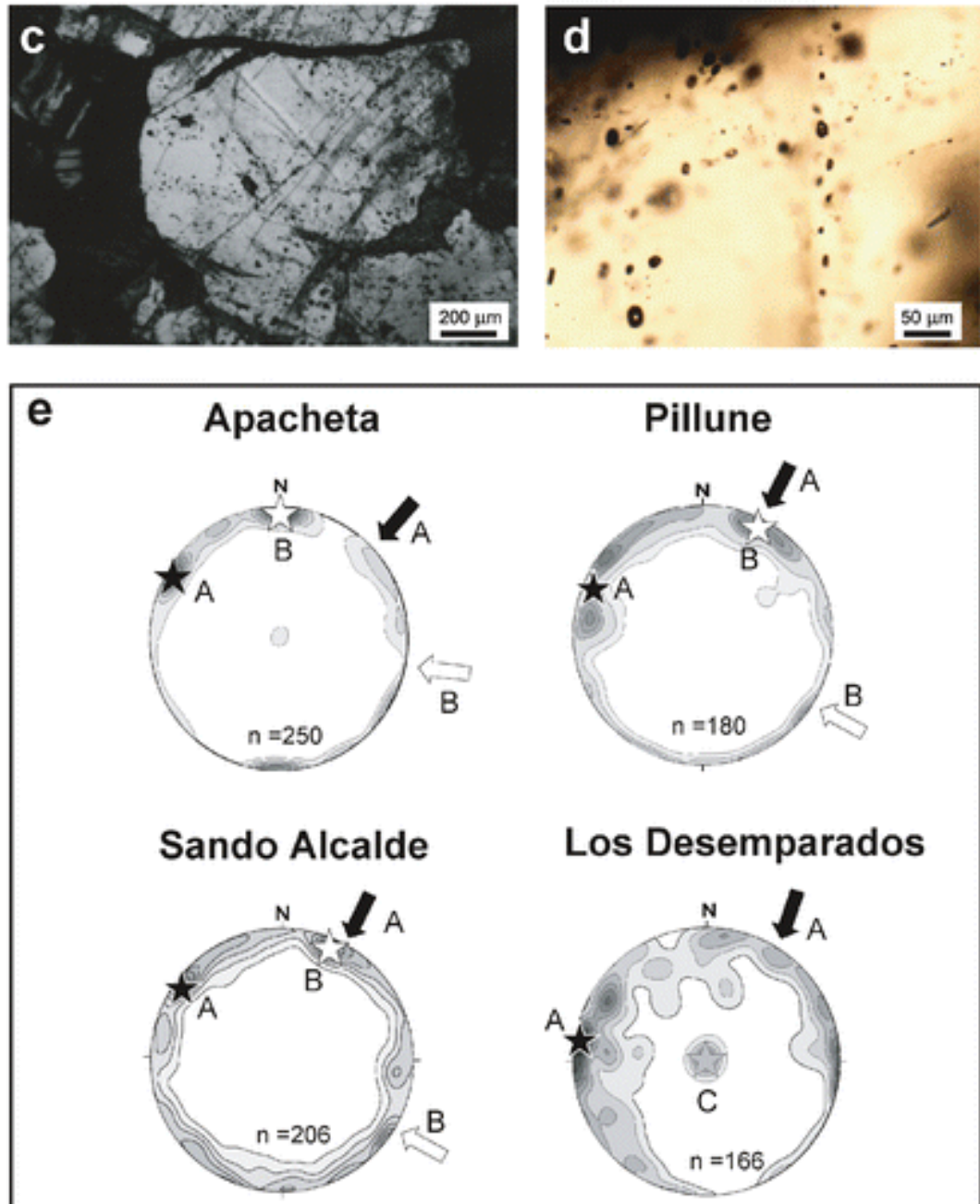

Fig. 13 Fluid inclusion plane (FIP) geometry. a Mode of FIP formation by fracturing and healing (Roedder 1984). b Schematic position of FIP with respect to $\sigma 1$ and $\sigma 3$ stress (Atkinson 1987). c and d FIP within magmatic quartz grains. e Stereonet diagrams showing the distribution of FIP within selected samples from the Apacheta, Pillune, Sando Alcalde, and Los Desemparados areas (see text for explanation)

The geometric parameters of the FIP sets were characterized by image analysis on oriented double-polished plates (Fig. 13c,d; Lapique et al. 1988). To be able to characterize the tectonic events that prevailed during the emplacement of the mineralized veins, FIP analyses were carried out on quartz grains of the volcanic matrix. The results are shown on four stereonet diagrams, which demonstrate that the FIP are located along two major orientations (Fig. 13e). At Apacheta, Pillune, and Sando Alcalde, the planes are subvertical and trend NNE-SSW (Family A, Fig. 13e) and approximately E-W (Family B, Fig. 13e). At Los Desemparados, the network shows a larger spread, but two main orientations are still visible: 
one subvertical with an approximate $\mathrm{N}-\mathrm{S}$ orientation (A) and the other horizontal (C). No relative chronology could be established between these plane families from optical thinsection observations.

\section{Characteristics of the hydrothermal fluids}

Paleofluid characterization was carried out on all deposits of the Shila, Ticlla, Puncuhuayco, Los Desemparados, and Paula areas using standard fluid-inclusion techniques. The microthermometric measurements were performed with a Chaixmeca heating-freezing stage (Poty et al. 1976) and salinity (expressed in $\mathrm{wt} \% \mathrm{NaCl}$ ) was calculated using equations from Bodnar (1993). The presence and the molar fraction of gas $\left(\mathrm{CO}_{2}, \mathrm{H}_{2} \mathrm{~S}, \mathrm{~N}_{2}\right)$ were determined in individual fluid inclusions by Raman microprobe analyses with a Dilor X-Y multichannel modular Raman spectrometer (Dubessy et al. 1984).

Petrography According to the criteria of Roedder (1984) and Bodnar et al. (1985), the studied fluid inclusions are either primary or secondary in origin. Three types of inclusion were observed in the ore-stage: vapor-rich $(\mathrm{V})$ with a high $\mathrm{Rv}$ ratio $(\mathrm{V} / \mathrm{L}+\mathrm{V})$ greater than $70 \%$, liquid-vapor (LV) with a constant Rv ratio of 10 to $20 \%$, and liquid-only (L) (Table 2). The fluid inclusions from the mineralized veins are hosted by sphalerite (stages 1 and 2), quartz (stage 2), and calcite (stage 2). No microthermometric measurement was made within the quartz grains of the volcanic host rock, mainly because of the very small size of the inclusions and also because of their questionable relationships with the mineralization.

Table 2 Fluid inclusion characteristics and microthermometric data

\begin{tabular}{|c|c|c|c|c|c|c|c|c|c|c|}
\hline $\begin{array}{l}\text { Inclusion } \\
\text { type }\end{array}$ & Deposit & $\begin{array}{l}\text { Host } \\
\text { mineral }\end{array}$ & & $\operatorname{Rv}(\%)$ & $\begin{array}{l}\mathbf{T m}_{\text {ice }}\left({ }^{\circ} \mathbf{C}\right) \\
\text { (melting } \\
\text { ice) }\end{array}$ & $\begin{array}{l}\text { Th } \\
\left({ }^{\circ} \mathbf{C}\right)\end{array}$ & Salinity & $\mathbf{T} \mathbf{m}_{\mathrm{co} 2}$ & $\mathbf{T h}_{\mathrm{co} 2}$ & $\begin{array}{l}\text { Tfc (fusion } \\
\text { clathrate) }\end{array}$ \\
\hline \multirow{7}{*}{ LV } & Ticlla & $\begin{array}{l}\text { Sphalerite } \\
1\end{array}$ & Primary & $10-30$ & $\begin{array}{l}-3.7 \quad \text { to } \\
-11.5(28)\end{array}$ & \begin{tabular}{|l}
203 to \\
223 \\
$(28)$
\end{tabular} & $\begin{array}{ll}6 & \text { to } \\
15.5 & \end{array}$ & - & - & - \\
\hline & & & Secondary & & $\begin{array}{l}-0.2 \text { to }-1.5 \\
(46)\end{array}$ & $\begin{array}{l}220 \text { to } \\
337 \\
(46)\end{array}$ & $\begin{array}{ll}0.4 & \text { to } \\
2.6 & \end{array}$ & - & - & - \\
\hline & & Quartz & Secondary & & $\begin{array}{l}-0.4 \text { to }-1.5 \\
(58)\end{array}$ & \begin{tabular}{|l}
218 to \\
236 \\
$(33)$
\end{tabular} & $\begin{array}{|ll|}0.7 & \text { to } \\
2.6 & \end{array}$ & - & - & - \\
\hline & Puncuhuayco & $\begin{array}{l}\text { Sphalerite } \\
1\end{array}$ & Primary & $10-30$ & $\begin{array}{ll}-8.5 & \text { to }-9 \\
(19) & \end{array}$ & \begin{tabular}{|l}
196 to \\
274 \\
$(19)$
\end{tabular} & \begin{tabular}{|l|}
12. \\
12.8
\end{tabular} & - & - & - \\
\hline & & & Secondary & & $\begin{array}{l}-0.2 \text { to }-1.1 \\
(26)\end{array}$ & \begin{tabular}{|l}
267 to \\
323 \\
$(26)$
\end{tabular} & $\begin{array}{ll}0.3 & \text { to } \\
1.9 & \end{array}$ & - & - & - \\
\hline & & Quartz & Secondary & & $\begin{array}{l}-0.5 \text { to }-1.1 \\
(28)\end{array}$ & \begin{tabular}{|l}
240 to \\
260 \\
$(28)$
\end{tabular} & $\begin{array}{ll}0.9 & \text { to } \\
1.9 & \end{array}$ & - & - & - \\
\hline & Los Desemparados & Quartz & Secondary & $10-20$ & -0.1 to -1.3 & \begin{tabular}{|l|}
175 to \\
246 \\
$(39)$
\end{tabular} & $\begin{array}{ll}0.2 & \text { to } \\
2.2 & \end{array}$ & - & - & - \\
\hline \multirow[t]{3}{*}{ LV } & Apacheta & $\begin{array}{l}\text { Sphalerite } \\
1\end{array}$ & Primary & $10-30$ & $\begin{array}{l}-4 \text { to }-6.3 \\
(13)\end{array}$ & $\begin{array}{l}258 \text { to } \\
271 \\
(13)\end{array}$ & $\begin{array}{ll}6.4 & \text { to } \\
9.5 & \end{array}$ & - & - & - \\
\hline & & $\begin{array}{l}\text { Quartz } \\
\text { Calcite }\end{array}$ & & & & & & & & \\
\hline & & Snhalerite & Primary & & -0.3 to -0.5 & 275 to & 06 to & $I_{-}$ & _ & - \\
\hline
\end{tabular}




\begin{tabular}{|c|c|c|c|c|c|c|c|c|c|c|}
\hline $\begin{array}{l}\text { Inclusion } \\
\text { type }\end{array}$ & Deposit & $\begin{array}{l}\text { Host } \\
\text { mineral }\end{array}$ & & $\operatorname{Rv}(\%)$ & $\begin{array}{l}\mathrm{Tm}_{\text {ice }}\left({ }^{\circ} \mathrm{C}\right) \\
\text { (melting } \\
\text { ice) }\end{array}$ & $\begin{array}{l}\text { Th } \\
\left({ }^{\circ} \mathbf{C}\right)\end{array}$ & Salinity & $\mathbf{T} \mathbf{m}_{\text {co2 }}$ & $\mathbf{T h}_{\mathrm{co} 2}$ & $\begin{array}{l}\text { Tfc (fusion } \\
\text { clathrate) }\end{array}$ \\
\hline & & 2 & & & (5) & $\begin{array}{l}285 \\
(5)\end{array}$ & 0.9 & & & \\
\hline & Sando Alcade & $\begin{array}{l}\text { Sphalerite } \\
1\end{array}$ & Secondary & $10-30$ & $\begin{array}{l}-2.5 \text { to }-4.8 \\
(10)\end{array}$ & \begin{tabular}{|l}
285 to \\
315 \\
$(8)$
\end{tabular} & $\begin{array}{ll}4.2 & \text { to } \\
7.6 & \end{array}$ & - & - & - \\
\hline & & Quartz & Primary & $10-30$ & $\begin{array}{l}-3.1 \text { to }-6.5 \\
(24)\end{array}$ & $\begin{array}{l}305 \text { to } \\
321 \\
(20)\end{array}$ & $\begin{array}{ll}5.1 & \text { to } \\
9.9 & \end{array}$ & - & - & - \\
\hline & & Calcite & Secondary & & $\begin{array}{l}-0.1 \text { to to } \\
-1.7 \text { (63) }\end{array}$ & \begin{tabular}{|l}
278 to \\
325 \\
$(50)$
\end{tabular} & $\begin{array}{ll}0.2 & \text { to } \\
2.9 & \end{array}$ & - & - & - \\
\hline & Pillune & Quatz & Primary & $10-30$ & $\begin{array}{l}-2.2 \text { to }-4.6 \\
(25)\end{array}$ & $\begin{array}{l}240 \text { to } \\
267 \\
(15)\end{array}$ & $\begin{array}{ll}3.7 & \text { to } \\
7.3 & \end{array}$ & - & - & - \\
\hline & & Calcite & Secondary & & $\begin{array}{l}0.8 \text { to }-1.6 \\
(55)\end{array}$ & $\begin{array}{l}240 \text { to } \\
280 \\
(15)\end{array}$ & $\begin{array}{ll}1.4 & \text { to } \\
2.7 & \end{array}$ & - & - & - \\
\hline & Paula & $\begin{array}{l}\text { Quartz } \\
\text { Calcite }\end{array}$ & $?$ & $10-30$ & $\begin{array}{l}0 \text { to }-0.7 \\
(13)\end{array}$ & $\begin{array}{l}162 \text { to } \\
302 \\
(23)\end{array}$ & & & & \\
\hline V & $\begin{array}{lr}\text { Apacheta } & \text { Sando } \\
\text { Alcade } & \text { Pillune } \\
\text { Paula } & \end{array}$ & Quartz & $\begin{array}{l}\text { Primary and } \\
\text { Secondary }\end{array}$ & \begin{tabular}{|l|}
$10-100$ \\
Majority \\
between $70-$ \\
100
\end{tabular} & - & $\begin{array}{l}250 \text { to } \\
300 \\
(36)\end{array}$ & - & $\begin{array}{l}-57.9 \text { to } \\
-59.6 \\
(28)\end{array}$ & $\begin{array}{l}-4.3 \text { to } \\
+6.5 \\
(15) 0\end{array}$ & $\begin{array}{l}-2.3 \text { to }+7.0 \\
(21)\end{array}$ \\
\hline
\end{tabular}

Microthermometry The principal microthermometric characteristics of the fluids encountered in the different deposits are summarized in Table 2 and Fig. 14a. The LV fluids yield salinities comparable to those described for gold-silver-bearing epithermal systems (Hedenquist and Henley 1985), even though the presence of $\mathrm{CO}_{2}$ traces, detected by Raman spectroscopy, could contribute to the final ice melting and, thus, slightly increases the apparent salinity of the inclusions (e.g., Bozzo et al. 1973; Collins 1979). A salinity decrease is observed from the stage 1 to stage 2 sphalerite inclusions (Table 1, Fig. 14a). Microthermometric investigation of the V fluids, only observed in Apacheta, Pillune, Sando Alcalde, and Paula (Table 2), was hindered by the small volume of the liquid phase. Freezing and heating experiments were thus restricted to the larger inclusions with good optical properties. The rare $\mathrm{Th}_{\mathrm{CO} 2}$ obtained indicates a low-density fluid. 


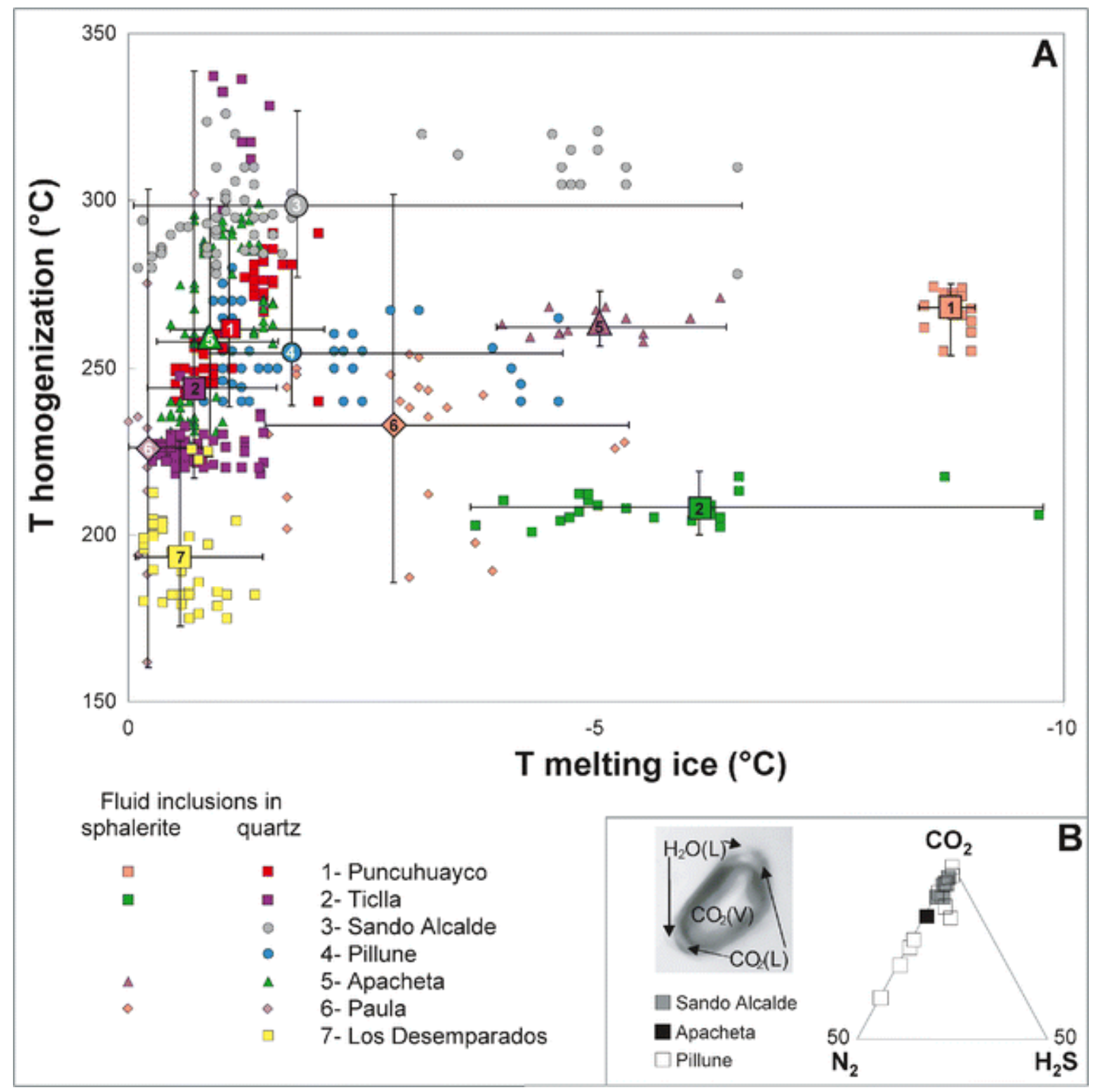

Fig. 14 a Microthermometric results for all analyzed fluid inclusions (LV and V types). b Gas proportions detected by Raman analysis of V-type-fluid inclusions

Raman analyses Raman analyses were conducted on the volatile phase of the LV and V fluid inclusions. For the LV fluids, the presence of minor $\mathrm{CO}_{2}$ was detected in the gaseous phase, but the low concentration excluded quantification. Nevertheless, because no clathrate formation was observed during the freezing stages, we suggest that the $\mathrm{CO}_{2}$ content may be below $3.7 \mathrm{wt} \%$ (Hedenquist and Henley 1985). For the $\mathrm{V}$ fluids, the volatile phase indicates the presence of $\mathrm{CO}_{2}(62.9$ to $100 \mathrm{~mol} . \%)$ with a lesser amount of $\mathrm{N}_{2}$ (0 to $\left.20.6 \mathrm{~mol} . \%\right)$ and $\mathrm{H}_{2} \mathrm{~S}(0.7$ to 6.7 mol.\%) (Fig. $14 \mathrm{~b})$.

Evidence for boiling In the Apacheta, Pillune, Sando Alcalde, and Paula sectors, the presence of many FIP containing only V-type inclusions, all of a similar size and with high $\mathrm{Rv}$ ratios, is a strong indicator of boiling because such filling cannot be linked to neckingdown phenomena (Bodnar et al. 1985). Moreover, adularia and platy calcite, commonly pseudomorphosed by quartz, have been observed in the four sectors (Figs. 8c and 12b). Based on the investigation of active geothermal systems, several studies have demonstrated that the coexistence of these minerals can be attributed to boiling phenomena (e.g., Browne 1978; 
Keith and Muffler 1978; Simmons and Christenson 1994). The coexistence of liquid-rich (LV) and vapor-rich (V) (not found within calcite) primary and secondary inclusions in stage 2 quartz and calcite (i.e., Sando Alcalde samples) also suggests that boiling was not restricted to this stage but occurred repeatedly during vein formation and probably during the late precious mineralization deposition stage.

\section{${ }^{40} \mathrm{Ar}{ }^{39} \mathrm{Ar}$ geochronology}

${ }^{40} \mathrm{Ar} /{ }^{39} \mathrm{Ar}$ laser-probe geochronology was applied to hydrothermal adularia crystals from different veins of the Shila/Paula district. The aims were to (1) back up previous K/Ar ages obtained on two samples from the Pillune and Sando Alcalde sectors (Cassard et al. 2000), (2) compare the ages of the Apacheta, Sando Alcalde, and Paula veins, and (3) characterize the duration of the hydrothermal event by dating stages 1 and 2. Analyzing adularia appears, according to the literature (Lang et al. 1994), to be particularly appropriate for precisely dating this kind of hydrothermal event. The analyses were performed at the Geochronology Laboratory of the University of Montpellier (France) using procedures along the lines of those described in Monié et al. (1997) and Dimo-Lahitte et al. (2001).

\section{Analytical method and sample characteristics}

Ten samples were preselected, but, due to the small size of adularia grains, single-grain separation was possible for only three of the samples (SA30, SA14, and PE59b; see Figs. 4a, and $5 \mathrm{~d}$ for location). Direct laser fusion on adularia grains in thin-section was also attempted but without success, probably because of a parasite response from surrounding minerals, such as quartz, that strongly affects measurements with a large percentage of atmospheric contamination. Consequently, only results obtained by laser-probe step heating on single adularia grains are presented and interpreted here.

Sample SA30 was collected from Apacheta Vein 2 at level 5,150 m (Fig. 5c). It is characterized essentially by stage 2 mineralogy where the adularia is coeval with quartz and calcite. The other two samples came from the Sando Alcalde area: Sample PE59b from the core of the main vein 74 in which brecciated stage 1 is overprinted by stage 2 veinlets and geodes (Fig. 3d); Sample SA14 from the core of a small vein parallel and coeval to vein 75 in which only stage 2 is represented (Fig. 5d).

\section{Results and interpretation}

The results are given in Fig. 15 as both plateau and isochron ages. Significant plateau ages were available for each sample and they are systematically consistent with the isochron ages, themselves having initial ${ }^{40} \mathrm{Ar} /{ }^{36} \mathrm{Ar}$ close to the atmospheric value of $295\left({ }^{36} \mathrm{Ar} /{ }^{40} \mathrm{Ar}\right.$ close to 0.0034). Samples SA30 and SA14 (stage 2 from Apacheta and Sando Alcalde, respectively) yielded very similar ages around $10.8 \pm 0.3 \mathrm{Ma}$ for more than $80 \%$ of the argon released (Fig. 15a,b), which is consistent with the earlier $\mathrm{K}-\mathrm{Ar}$ age published for the Pillune and Sando Alcalde mineralization (approximately $10 \mathrm{Ma}$, Cassard et al. 2000). The results for Sample PE59b require more attention; the age spectrum exhibits a plateau age of $11.44 \pm 0.35 \mathrm{Ma}$ for about $60 \%$ of the gas released, with a weak depletion for the first heating 
increments that could be the result of Ar loss during a more recent thermal overprint (Fig. 15c).
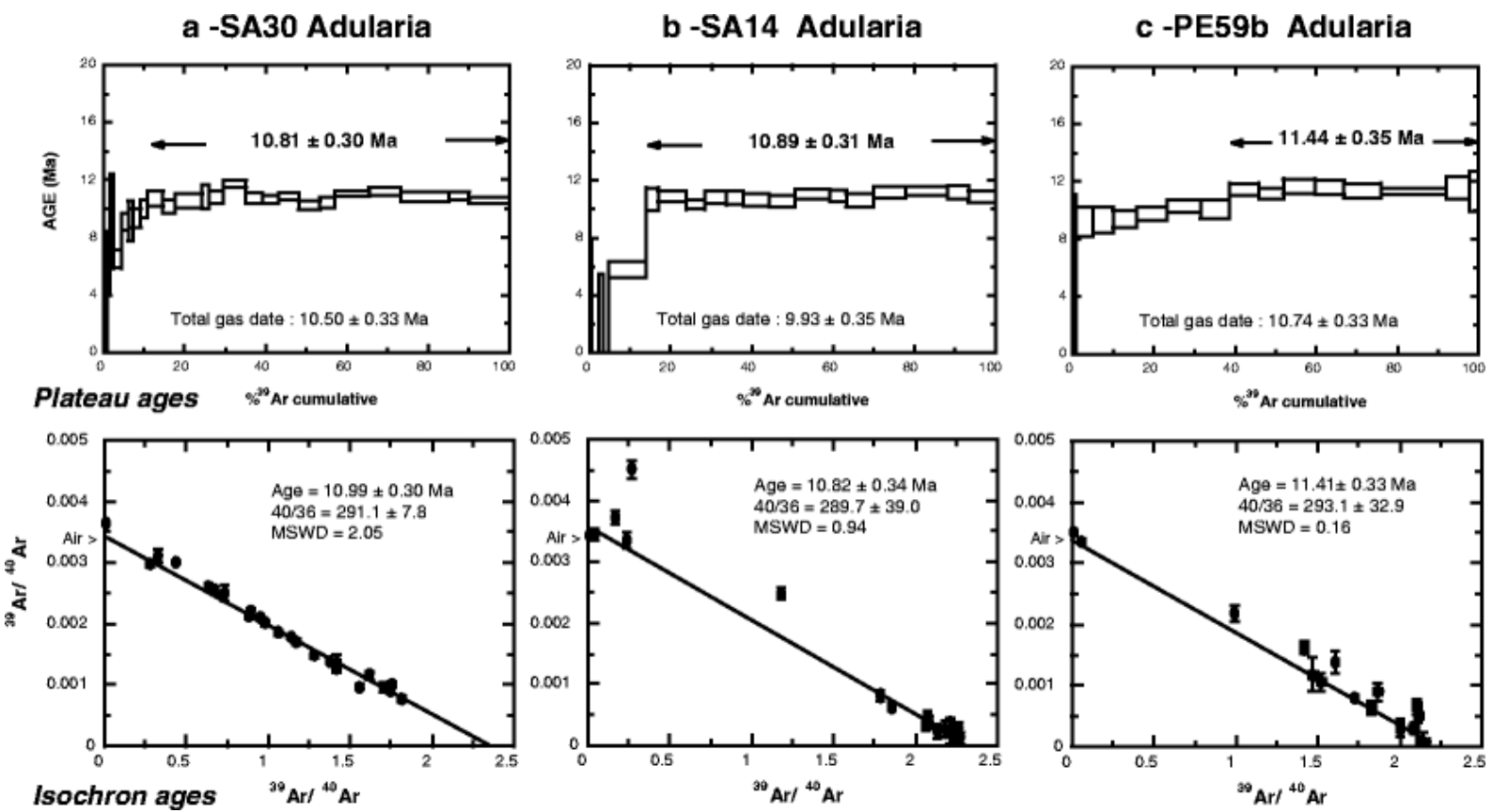

Fig. $15{ }^{40} \mathrm{Ar} /{ }^{39} \mathrm{Ar}$ results for the three analyzed samples represented by plateau-age spectra and isochron diagrams

Compared to the preliminary K/Ar ages (Cassard et al. 2000), the paragenetic position of the analyzed adularia with respect to the two mineralogical stages (stages 1 and 2) is precisely known here. Moreover, although our data first confirmed that the gold mineralization of the Shila area (Pillune, Sando Alcalde, and Apacheta sectors) developed generally during the Late Miocene, close to 10.8-10.5 Ma, we suggest that this age probably corresponds to the stage 2 mineralization. The results obtained on Sample PE59b, in which both stages 1 and 2 are represented, remain difficult to interpret. However, the fact that we obtain a relatively older age (within the error bars), apparently rejuvenated by a subsequent thermal event, leads us to interpret this older age as that of stage 1.

\section{Discussion \\ Main results}

The main results of our structural, mineralogical, textural, microthermometric, and geochronological study of the Shila-Paula vein systems are as follows:

1. We find paragenetic associations that characterize a low-sulfidation epithermal mineralization with extensive gold-bearing veins and a typical adularia-quartz-sericite paragenesis associated with Mn-rich minerals. Although this result has been described previously (Milési and Marcoux 1990), the existence of two stages of mineralization and two distinct vein systems is particularly well illustrated here. The main veins are oriented $\mathrm{N} 90^{\circ} \mathrm{E}$ and the secondary veins trend $\mathrm{N} 60^{\circ} \mathrm{W}$. 
2. The stage 1 mineralization is expressed mainly as $\mathrm{E}-\mathrm{W}$ brecciated veins filled by quartz, base-metal sulfides, Mn-silicates, and subsequent Mn-carbonates (Fig. 7a). Gold was deposited during this stage in the form of electrum (Fig. 8d), although the more economic grades appear to be related to stage 2 .

3. The stage 2 mineralization is found only within the secondary $\mathrm{N} 45-60^{\circ} \mathrm{W}$ veins, and within geodes and open cavities within stage 1-related E-W veins (Fig. 7a). This second mineralizing event began with the crystallization of coarse-grained quartz, adularia, and platy calcite and ended with the formation of a 'Bonanza' substage represented by the main ore bodies. The Bonanza substage comprised a few successive stages of silica deposition and base-metal assemblages, in places with abundant electrum and silverbearing minerals (Fig. 11f,g).

4. Stage 2, and particularly the Bonanza substage, makes up the major part of the Nazareño vein fill in the Paula area (Fig. 7b). These veins, mainly oriented $\mathrm{N} 60^{\circ} \mathrm{W}$, exhibit open-type structures that could reflect their formation as tension gashes within a stress-free environment.

5. Even though this result needs to be considering with care, the fluid-inclusion plane (FIP) studies demonstrate the existence of two trends of extensional fractures consistent with two major compressive directions with NNE-SSW and ESE-WNW orientations. A slight rotation of these two orientations is seen at Apacheta (still enigmatic in terms of vein orientation) and the ESE-WNW direction is absent at Los Desemparados.

6. Salinity and temperature conditions given by the fluid inclusions are typical of a lowsulfidation environment, with salinity decreasing from early $(4.2$ to $15.5 \mathrm{wt} \% \mathrm{NaCl})$ to late stage $(0.2$ to $2.9 \mathrm{wt} \% \mathrm{NaCl})$, and low-density fluids. All the $\mathrm{Au}-\mathrm{Ag}$ rich ore deposits (Apacheta, Pillune, Sando Alcalde, and Paula) show evidence of boiling with only vaporrich inclusions of similar size.

7. Preliminary ${ }^{40} \mathrm{Ar} /{ }^{39} \mathrm{Ar}$ dating of selected adularia crystals demonstrates that the veins were formed at about $11 \mathrm{Ma}$. One important result is the short time difference noted, within error bars, between the results from the stage 1 (sample PE59b) and stage 2 (samples SA14, SA30) adularia. The stage 1 adularia yield ages older by about $0.6 \mathrm{Ma}$ with respect to the others (Fig. 15). This point needs to be confirmed by additional age determinations, which are currently in progress.

\section{The Shila-Paula mineralization model}

To understand the mineralization process, we have to resolve the paradox highlighted by the mesoscale geometric relationships. It is necessary to explain the coexistence of sinistral shearzone type geometries (defined by the systematic association of main and secondary veins with a constant angular relationship) with a schistosity (secondary vein) opened and filled by euhedral quartz and other minerals (stage 2). There are two possibilities:

1. the development of a sequential vein system, which implies a systematic rotation of the opening direction (Stowell et al. 1999); 
2. the intervention of two successive events, one giving rise to the shear-zone geometry and the other to the reopening and filling of preexisting structures (Chauvet et al. 1999; Cassard et al. 2000).

Because we have two distinct textures that correspond to different filling stages (breccia and open space) within the main and secondary veins, we favor the latter possibility that the structures result from two successive tectono-mineralizing stages separated into three phases of formation, as illustrated in Fig. 16.

1. The first phase corresponds to stage 1 and is assumed to have developed under the effects of a NE-SW shortening direction that helped form the E-W oriented sinistral shear zones (Fig. 16a). An associated $\mathrm{N} 60^{\circ} \mathrm{W}$ cleavage (future or next secondary veins) was also created. The NNE-SSW direction of shortening given by the FIP analysis (Fig. 13e) could correspond to this stage. Coeval with their formation, the structures were filled by stage 1 ore fluids. With ongoing deformation, the resultant mineralization became brecciated, thus forming the characteristic stage $1 \mathrm{Mn}$-rich breccia (Figs. 3d and 16a). We assume that tectonic displacement remained weak and that the ongoing brecciation was strongly helped by hydraulic fracturing, as illustrated by several typical features (Fig. 3e). The first $\mathrm{N} 70^{\circ} \mathrm{E}$ to $\mathrm{N} 90^{\circ} \mathrm{E}$ oriented veins (Juliana and Lucia) in the Paula domain may have formed during this phase; they are filled only by quartz and display some sinistral shear features (Fig. 6e). Because of its specific lithology, the Apacheta vein system is assumed not to have developed such sinistral shear zones. In fact, the veins appear to have developed essentially parallel to, and thus under the control of, the main faults in the area (Fig. 3a).

2. The second phase was a reopening of the earlier-formed structures (Fig. 16b). This event consists in stage 2 (Pre-bonanza and Bonanza substages) (Fig. 16). Stage 2 may have been initiated with the crystallization of rare sulfides and rhodochrosite, followed by quartz, adularia, and platy calcite, that mainly fill the secondary veins (reopened former schistosity) and geodes within the early breccia (Fig. 16b). We assume that this stage was controlled by a NW-SE shortening direction (Fig. 16b) that assisted the reopening of the earlier schistosity and the formation of the scarce N50 ${ }^{\circ}$ E-trending S2 cleavages (Fig. 5e,f). This stage is also recognized from the FIP analyses (Fig. 13e). The dextral motion observed along the $\mathrm{N} 30^{\circ} \mathrm{W}$ secondary vein of Pillune Vein 14 could be interpreted as antithetic motion developed during this phase (Fig. 11c), taking into account that no displacement is observed on the $\mathrm{N} 60^{\circ} \mathrm{W}$ veins in this area (see above). Such a stage in the Paula area could have caused the opening of the Nazareño veins as tension-gashes (Mode I crack; Atkinson 1987), thus explaining its thickness and open-type internal texture.

3. Formation of the so-called 'Bonanza' mineralization (stage 2) that developed within restricted parts of the Sando Alcalde (Vein 75) and Apacheta sectors (Fig. 16c). Conversely, it represents the main filling of the Paula vein system (i.e., the Nazareño veins; Fig. 16c). 


\section{Shila district (Sando Alcalde) Paula district (Nazareno)}
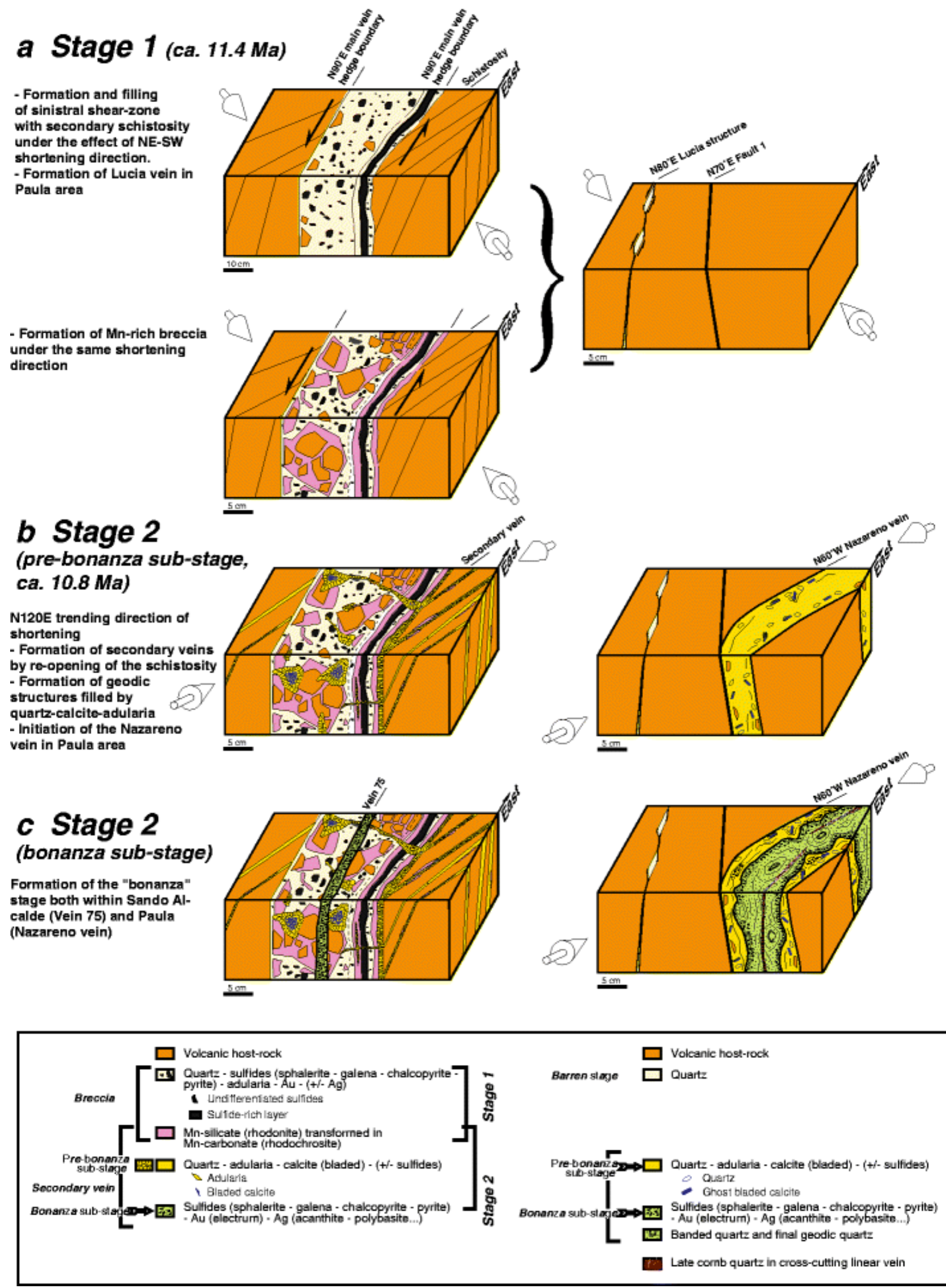

Fig. 16 Three-stage model explaining the formation of the gold-bearing vein system of the Shila-Paula district. See text for explanation 
On a regional scale, we assume that during the first event, with the formation of the stage 1 Mn-rich mineralization in the Shila district, there was little or no metal deposition in the Paula area, other than possibly the emplacement of the poorly mineralized San Carlos deposit (Fig. 16a). The Nazareño vein system in the Paula area was formed during a second event as tension gashes with respect to the tectonic stress controlled by a NW-SE direction of shortening (Fig. 16c), with the Bonanza mineralization being deposited during the end of stage 2 . In the Shila district, the schistosity of the first-phase structures, which displays the same direction, was reopened and filled by the stage 2 ore fluid.

The occurrence of typical platy calcite demonstrates that a boiling process was active during the second stage (Simmons and Christenson 1994). The fluid inclusion data help in its identification (this work and André-Mayer et al. 2002). The intervention of boiling may explain the relatively haphazard localization of the second-stage-related mineralization within the main earlier veins (Fig. 7a). We suggest that the stage 2 mineralization crystallized within zones where apertures enabled the necessary pressure decrease for boiling and subsequent ore precipitation.

The formation model proposed here for the Shila and Paula $\mathrm{Au}-\mathrm{Ag}$ mineralization has the advantage of integrating most of the mineralized veins, even though a few sectors such as Apacheta appear to be inconsistent with the synoptic history. Adoption of the model nevertheless leaves three major questions unanswered, i.e., (1) what were the vein opening conditions during the first phase? (2) did the reopening during the second phase result from either a further tectonic event or the action of hydraulic fracturing controlled by fluid overpressure? and (3) how can the two directions of shortening be integrated within a regional setting?

\section{Constraints on the opening process}

The brecciated texture of the main veins could be interpreted as a typical breccia-pipe feature associated with a typical regular sheeting (the secondary veins; e.g., Sillitoe 1985). This hypothesis, however, can be eliminated because of the relative thinness of the veins, the existence of a constant angle between the main and secondary veins, and the fact that the fillings of the two structures are different. We thus propose that the main vein formation resulted from left-lateral shearing that was responsible for breccia occurrence, even though hydraulic fracturing cannot be excluded (see above). The direction of maximum shortening was close to NE-SW. The same assumption was made by Bradford (1999) for the filling of the east-to-northeast-trending veins of the Poracota prospect (see location on Fig. 1).

For the secondary veins, we have seen earlier that the structures related to the stage 2 mineralization are characteristics of mode I cracks, parallel to the direction of maximum shortening. We consider that these structures reflect a filling that was coeval with the vein opening and, consequently, that they reflect a syntectonic vein formation.

\section{Regional implications}

Our adopted model implies two distinct tectonic stages, both associated with fluid emplacement. The direction of the first compression could be easily correlated with the wellknown Quechua II tectonic event that gave rise to a NE-SW shortening throughout the Cordillera at around 10-12 Ma (Soulas 1977; Pilger 1984; Pardo-Casas and Molnar 1987). 
Such ages are in good agreement with those obtained for the formation of the Shila mineralization at around $11 \mathrm{Ma}$. The second direction of shortening, trending SE-NW, is more difficult to integrate within the regional context. For this reason, we can question whether the stage 2 mineralization, mainly characterized by open-type structures, resulted only from the application of a tectonic stress or whether it was the consequence of opening under fluid overpressure (hydraulic fracturing). It is very difficult to find a clear answer to this question. The presence, within several places, of a secondary $\mathrm{N} 50^{\circ} \mathrm{E}$ schistosity (S2) favors the existence of a NW-SE direction of shortening. However, the systematic open-style texture that characterizes stage 2, associated with the few indications of a boiling process, argues in favor of a significant participation of fluid overpressure during the stage 2 mineralization. A recent detailed analysis of the Apacheta fluid inclusions concluded that boiling has been associated with overpressure and subsequent rupture and hydrothermal brecciation (AndréMayer et al. 2002). In fact, it is quite possible for tectonics and fluid overpressure to have functioned simultaneously.

\section{Conclusion}

Mainly based on internal textural analysis combined with structural, mineralogical fluid inclusion and geochronological data, our proposed model demonstrates the role of earlierformed tectonic features and the importance of their reutilization for forming mineralized structures. We should emphasize that the stage 2 bonanza mineralization, which is of most economic interest, has nowhere been encountered directly within the country rocks. This fact may explain why most of the low-sulfidation epithermal mineralization is composed of complex and multistage veins with an earlier Mn stage followed by quartz-rich and bonanza stages (i.e., Gibson et al. 1990; Shimizu et al. 1998). Our study reveals that such a complex internal texture, even though it certainly results from variations of fluid chemistry and physico-chemical conditions (e.g., Dowling and Morrison 1989; Dong et al. 1995), can also result from structural and lithological changes. In fact, the pre-existence of prevailing traps, such as the main veins, is crucial for the distribution and formation of subsequent ore concentration. In addition, the nature and structure of the country rock also seems to play a crucial role, as illustrated by the very different patterns of the mineralized veins within the pyroclastites (Sando Alcalde and Pillune sectors), the volcanic breccias (Apacheta sector) and the dacitic/andesitic lavas (Paula area). These lithological contrasts help to explain the very different vein geometry, texture, and distribution within the Apacheta sector and the occurrence of only stage 2-related structures in the Paula area. Such point of view should be taken into account by exploration programs for gold-bearing veins in an epithermal context.

Acknowledgements This study was greatly helped by Cedimin S.A., a subsidiary of Compania de Minas Buenaventura, which assisted us throughout our stay in Peru with logistics and mine visits. We particularly thank J. M. Georgel for his constant help and U. Ruiz, J. C. Yufra and H. Herreas for field assistance and fruitful discussions. We also acknowledge Alberto Benavides de la Quintana for giving us the authorization to carry out the work and for his consistent support. Field and laboratory work were financed by the CNRS through the CNRS-GDR Metallogeny research program (gold theme) and by the BRGM 'Andes' research project, which also provided the funds for ${ }^{40} \mathrm{Ar} /{ }^{39} \mathrm{Ar}$ dating. W. T. Parry is acknowledged for comments on an earlier version of this manuscript. Careful reviews by B. Lehmann and B. Silberman helped to improve this manuscript. 


\section{References}

André AS, Sausse J, Lespinasse M (2001) New approach for the quantification of paleostress magnitudes: applications to the Soultz vein system (Rhine graben, France). Tectonophysics $336: 215-231$

André-Mayer AS, Leroy J, Bailly L, Chauvet A, Marcoux E, Grancea L, Llosa F, Rosas J (2002) Boiling and vertical mineralization zoning: a case study from the Apacheta lowsulfidation epithermal gold-silver deposit, southern Peru. Miner Depos 37:452-464

Atkinson BK (1987) Fracture mechanics of rock. Academic, Orlando, p 534

Bodnar RJ (1993) Revised equation and table for determining the freezing point depression of $\mathrm{H}_{2} \mathrm{O}-\mathrm{NaCl}$ solutions. Geochim Cosmochim Acta 57:683-684

Bodnar RJ, Reynolds TJ, Kuehn CA (1985) Fluid inclusion systematics in epithermal systems. In: Berger BR, Bethke PM (eds) Geology and geochemistry of epithermal systems. Rev Econ Geol 2:73-97

Bozzo AT, Chen HS, Kass JR, Barduhn AJ (1973) The properties of the hydrates of chlorine and carbon dioxide. In: 4th international symposium on fresh water from the sea, vol 3, pp $437-451$

Bradford J (1999) Poracota: un yacimiento epitermal de oro de alta sulfuración en el sur del Perú. In: Primer Congreso Internacional de prospectores y exploradores ProExplo 99:49-59

Browne PRL (1978) Hydrothermal alteration in active geothermal fields. Annu Rev Earth Planet Sci 6:229-250

Candiotti de Los Rios H, Noble DC, Mc Kee EH (1990) Geologic setting and epithermal silver veins of the Arcata District, Southern Peru. Econ Geol 85:1473-1490

Cassard D, Chauvet A, Bailly L, Llosa F, Rosas J, Marcoux E, Lerouge C (2000) Structural control and K/Ar dating of the $\mathrm{Au}-\mathrm{Ag}$ epithermal veins in the Shila Cordillera, southern Peru. C R Acad Sci Paris, Sciences Terre Planètes 330:23-30

Cathelineau M, Lespinasse M, Bastoul AM, Bernard C, Leroy JL (1990) Fluid migration during contact metamorphism: the use of oriented fluid inclusion trails for a time/space reconstruction. Mineral Magazine 54:169-182

Chauvet A, Cassard D, Bailly 1 (1999) Process of formation of the Au-Ag Shila-Paula epithermal veins system (southern Peru). Fourth ISAG (International Symposium on Andean Geodynamics), Göttingen, Germany, October 4-6, 1999 Extended Abstr, 159-162

Clark AH, Farrar E, Kontak DJ, Langridge RJ, Arenas FMJ, France LJ, McBride SL, Woodman PL, Wasteneys HA, Sandeman HA, Archibald DA (1990) Geologic and geochronologic constraints on the metallogenic evolution of the Andes of southeastern Peru. Econ Geol 85:1520-1583 
Cline JS, Bodnar RJ, Rimstidt JD (1992) Numerical simulation of fluid flow and silica transport and deposition in boiling hydrothermal solutions: application to epithermal gold deposits. J Geophys Res 97:9085-9103

Cole DR, Drummond SE (1986) The effect of transport and boiling on Ag/Au ratios in hydrothermal solutions: a preliminary assessment and possible implications for the formation of epithermal precious-metal ore deposits. J Geochem Explor 25:45-79

Collins PLF (1979) Gas hydrates in $\mathrm{CO}_{2}$ bearing fluid inclusions and the use of freezing data for estimation of salinity. Econ Geol 74:1435-1444

Cooke DR, McPhail DC (2001) Epithermal Au-Ag-Te mineralization, Acupan, Baguio District, Philippines: numerical simulations of mineral deposition. Econ Geol 96:109-131

Cox SF, Etheridge MA (1983) Crack-seal fibre growth mechanisms and their significance in the development of oriented layer silicate microstructures. Tectonophysics 92:147-170

De Ronde CEJ, Blattner P (1988) Hydrothermal alteration, stable isotopes, and fluid inclusions of the Golden Cross epithermal gold-silver deposit, Waihi, New Zealand. Econ Geol 83:895-917

Dimo-Lahitte A, Monié P, Vergély P (2001) Metamorphic soles from the Albanian ophiolites: petrology, ${ }^{40} \mathrm{Ar} /{ }^{39} \mathrm{Ar}$ geochronology and geodynamic evolution. Tectonics 80:78-96

Dong G, Morrison G, Jaireth S (1995) Quartz textures in epithermal veins, Queenslandclassification, origin, and implication. Econ Geol 90:1841-1856

Dowling K, Morrison G (1989) Application of quartz textures to the classification of gold deposits using North Queensland examples. Econ Geol Monogr 6:342-355

Drummond SE, Ohmoto H (1985) Chemical evolution and mineral deposition in boiling hydrothermal systems. Econ Geol 80:126-147

Dubessy J, Guilhaumou N, Mullis J, Pagel M (1984) Reconnaissance par microspectrometrie Raman, dans les inclusions fluides, de $\mathrm{H}_{2} \mathrm{~S}$ et $\mathrm{CO}_{2}$ solides à domaine de fusion comparable. Bull Minéral 107:189-192

Ericksen GE, Cunningham CG (1993) Precious-metal deposits in the Neogene-Quaternary complex of the Central Andes. Investigacion de Metales Preciosos en los Andes Centrales, Proyecto BID/TC-88-02-32-5, pp 3-16

Fletcher CJN, Hawkins MP, Tejada R (1989) Structural control and genesis of polymetallic deposits in the Altiplano and Western Cordillera of southern Peru. J South Am Earth Sci 2:61-71

Fornari M, Mamani M, Ibarra I, Carlier G (2002) Datación del periodico volcánico 'Tacaza' en el Altiplano de Perú y Bolivia. XI Congreso Peruano de Geología, Lima, 25-28 September 2002, p 21 
Genna A, Jébrak M, Marcoux E, Milési JP (1996) Genesis of cockade breccias in the tectonic evolution of the Cirotan epithermal gold system, West Java. Can J Earth Sci 33:93-102

Gibson PC, Noble DC, Larson LT (1990) Multistage evolution of the Calera epithermal AgAu vein system, Orcopampa district, southern Peru: first results. Econ Geol 85:1504-1519

Gibson PC, Mc Kee EH, Noble DC, Swanson KE (1995) Timing and interrelation of magmatic, tectonic and hydrothermal activity at the Orcopampa district, Southern Peru. Econ Geol 90:2317-2325

Gratier JP (1984) La déformation des roches par dissolution-cristallisation. Unpublished Ph.D. thesis, University of Grenoble, France, p 317

Greffié C, Bailly L, Milési JP (2002) Supergene alteration of primary ore assemblages from low-sulfidation $\mathrm{Au}-\mathrm{Ag}$ epithermal deposits at Pongkor, Indonesia, and Nazareño, Peru. Econ Geol 97:561-571

Hayashi KI, Maruyama T, Satoh H (2001) Precipitation of gold in a low-sulfidation epithermal gold deposit: insights from a submillimeter-scale oxygen isotope analysis of vein quartz. Econ Geol 96:211-216

Hayba DO, Bethke PM, Heald P, Foley NK (1985) Geologic, mineralogic, and geochemical characteristics of volcanic-hosted epithermal precious-metal deposits. In: Berger BR, Bethke PM (eds) Geology and Geochemistry of Epithermal Systems. Rev Econ Geol 2:129-166

Heald P, Foley NK, Hayba DO (1987) Comparative anatomy of volcanic-hosted epithermal deposits: acid-sulfate and adularia-sericite type. Econ Geol 82:1-26

Hedenquist JW, Henley RW (1985) The importance of $\mathrm{CO}_{2}$ on freezing point measurements of fluid inclusions: evidence from active geothermal systems and implications for epithermal ore deposition. Econ Geol 80:1379-1406

Hedenquist JW, Lowenstern JB (1994) The role of magmas in the formation of hydrothermal ore deposits. Nature 370:519-527

Horner JT, Enriquez E (1999) Epithermal precious metal mineralization in a strike-slip corridor: the San Dimas District, Durango, Mexico. Econ Geol 94:1375-1380

Jannas R (1998) Resumen consultario Proyecto Chipmo. Internal report. Buenaventura S.A.

Jébrak M (1997) Hydrothermal breccias in vein-type ore deposits: a review of mechanisms, morphology and size distribution. Ore Geol Rev 12:111-134

Keith TEC, Muffler LPJ (1978) Minerals produced during cooling and hydrothermal alteration of ash flow tuff from Yellowstone drill hole Y-5. J Volcanol Geotherm Res 3:373402

Klinck BA, Ellison RA, Hawkins MP (1986) The Geology of the Cordillera Occidental and Altiplano West of Lake Titicaca, Southern Peru. British Geological Survey and Instituto Geologíco Minero y Metalúrgico, Perú, p 340 
Kowallis BJ, Wang HF, Jang BA (1987) Healed microcrack orientations in granite from Illinois borehole UHP-3 and their relationship to the rock's stress history. Tectonophysics 135:297-306

Lang B, Edelstein O, Steinitz G, Kovacs M, Halga S (1994) Ar-Ar dating of adularia-a tool in understanding genetic relations between volcanism and mineralization: Baia Mare area (Guth Mountains), north western Romania. Econ Geol 89:174-180

Lapique F, Champenois M, Cheilletz A (1988) Un analyseur vidéographique interactif : description et applications. Bull Minéral 111:679-687

Laubacher G (1978) Estudio Geológico de la Región del Norte del Lago Titicaca. Instituto Geología y Minería, Perú, Boletín 5, p 120

Laubach SE (1989) Paleostress directions from the preferred orientation of closed microfractures (fluid inclusion planes) in sandstones, East Texas basin, USA. J Struct Geol $11: 603-611$

Lespinasse M (1999) Are fluid inclusion planes useful in structural geology. J Struct Geol $21: 1237-1243$

Lespinasse M, Pêcher A (1986) Microfracturing and regional stress field: a study of preferred orientations of fluid inclusion planes in a granite from the Massif Central, France. J Struct Geol 8:169-180

Llosa Tejada F, Rosas Vargas J, Bailly L, Chauvet A (2002) Control estructural y modelo de formación de las vetas epitermales Au-Ag de mina Paula. Arequipa: XI Congreso Peruano de Geología, Lima, 25-28 September 2002, p 97

Matsuhisa Y, Aoki M (1994) Temperature and oxygen isotope variations during the formation of the Hishikari epithermal gold-silver veins, southern Kyushu, Japan. Econ Geol 89:16081613

Mayta O (1999) Yacimiento aurifero Chipmo. In: Primero Congreso Internacional de prospectores y exploradores. ProExplo 99:37-49

Milési JP, Marcoux E (1990) Mineralogical and textural position of the $\mathrm{Au}-\mathrm{Ag}$ bearing minerals in the evolution of epithermal deposits of Orcopampa and Shila (southern Peru). BRGM report (unpublished)

Monié P, Caby R, Arthaud MH (1997) The Neoproterozoic Brasiliano orogeny in northeast Brazil: ${ }^{40} \mathrm{Ar} /{ }^{39} \mathrm{Ar}$ and petrostructural data from Ceara. Precamb Res 81:241-264

Moore JN, Adams MC, Lemieux MM (1992) The formation and distribution of CO2-enriched fluid inclusions in epithermal environments. Geochim Cosmochim Acta 56:121-135

Naito K (1993) Occurrences of quartz veins in the Hishikari gold deposits, Southern Kyushu, Japan. In: Shikazono N, Naito K, Izawa E (eds) High grade epithermal gold mineralizationthe Hishikari deposit. Resource Geol Spec Issue 14:37-46 
Newell ND (1949) Geology of the Lake Titicaca Region, Peru and Bolivia. Geol Soc Am Memoir 36:111

Pardo-Casas F, Molnar P (1987) Relative motion of the Nazca (Farallon) and South American plates since late Cretaceous time. Tectonics 6:233-248

Pêcher A, Lespinasse M, Leroy J (1985) Relation between fluid inclusion trails and regional stress field: a tool for fluid chronology. An example of an intragranitic uranium ore deposit (north-west Masif Central, France). Lithos 18:229-237

Petersen U (1965) Regional geology and major ore deposits of Central Peru. Econ Geol 60:407-470

Petersen EU, Petersen U, Hackbarth CJ (1990) Ore zoning and tetrahedrite compositional variation at Orcopampa, Peru. Econ Geol 85:1491-1503

Pilger RH (1984) Cenozoic plate kinematics, subduction and magmatism: South American Andes. J Geol Soc London 141:793-802

Plumlee GS (1994) Fluid chemistry evolution and mineral deposition in the main-stage Creede epithermal system. Econ Geol 89:1860-1882

Ponce DA, Glen JMG (2002) Relationship of epithermal gold deposits to large-scale fractures in northern Nevada. Econ Geol 97:3-9

Poty B, Leroy J, Jachimowicz L (1976) Un nouvel appareil pour la mesure des temperatures sous le microscope, l'installation de microthermométrie Chaix-Meca. Bull Soc Française Minéral Cristallo 99:182-186

Ramsay JG, Huber MI (1983) The technics of modern structural geology, vol. I: strain analysis. Academic, London, p 307

Reed MH, Spycher NF (1985) Boiling, cooling, and oxidation in epithermal systems: a numerical modeling approach. In: Berger BR, and Bethke PM (eds) Geology and geochemistry of epithermal systems. Rev Econ Geol 2:249-272

Roedder E (1984) Fluid inclusions. Rev Mineral 12:1-394

Shimizu T, Matsueda H, Ishiyama D, Matsubaya O (1998) Genesis of epithermal $\mathrm{Au}-\mathrm{Ag}$ mineralization of the Koryu mine, Hokkaido, Japan. Econ Geol 93:303-325

Sillitoe RH (1976) Andean mineralization: a model for the metallogeny of convergent plate margins. Geol Soc Can Spec Paper 14:59-100

Sillitoe RH (1985) Ore-related breccias in volcanoplutonic arcs. Econ Geol 80:1467-1514

Simmons SF, Christenson BW (1994) Origins of calcite in a boiling geothermal system. Am J Sci 294:361-400 
Soulas JP (1977) Les phases tectoniques andines du Tertiaire supérieur, résultats d'une transversale Pisco-Ayacucho (Pérou Central). C R Acad Sci Paris 284:2207-2210

Stowell JFW, Watson AP, Hudson NFC (1999) Geometry and population systematics of a quartz vein set, Holy Island, Anglesey, North Wales. In: McCaffrey KJW, Lonergan L, Wilkinson JJ (eds) Fractures, fluid flow and mineralization. Geol Soc Lond Spec Pub 155:1733

Tuttle OF (1949) Structural petrology of planes of liquid inclusions. J Geol 57:331-356

White NC, Hedenquist JW (1995) Epithermal gold deposits: styles, characteristics and exploration. SEG Newsletter 23:8-13 